\title{
Epigene and Hypogene Gypsum Karst Manifestations of the Castile Formation:Eddy County, New Mexico and Culberson County, Texas, USA
}

\author{
Kevin W. Stafford ${ }^{1,2}$, Raymond Nance ${ }^{3}$, Laura Rosales-Lagarde ${ }^{1,2}$, and Penelope J. Boston ${ }^{1,2}$
}

\begin{abstract}
:
Stafford K., Nance R., Rosales-Lagarde L. and Boston P.J. 2008. Epigene and Hypogene Gypsum Karst Manifestations of the Castile Formation: Eddy County, New Mexico and Culberson County, Texas, USA. International Journal of Speleology, 37 (2), $83-98$. Bologna (Italy). ISSN 0392-6672.

Permian evaporites of the Castile Formation crop out over $\sim 1,800 \mathrm{~km} 2$ in the western Delaware Basin (Eddy County, New Mexico and Culberson County, Texas, USA) with abundant and diverse karst manifestations. Epigene karst occurs as well-developed karren on exposed bedrock, while sinkholes dominate the erosional landscape, including both solutional and collapse forms. Sinkhole analyses suggest that more than half of all sinks are the result of upward stoping of subsurface voids, while many solutional sinks are commonly the result of overprinting of collapsed forms. Epigene caves are laterally limited with rapid aperture decreases away from insurgence, with passages developed along fractures and anticline fold axes. Hypogene karst occurs as diverse manifestations, forming the deepest and longest caves within the region as well as abundant zones of brecciation. Hypogene caves exhibit a wide range of morphologies from complex maze and anastomotic patterns to simple, steeply dipping patterns, but all hypogene caves exhibit morphologic features (i.e. risers, outlet cupolas and half-tubes) that provide a definitive suite of evidence of dissolution within a mixed convection (forced and free convection) hydrologic system. Extensive blanket breccias, abundant breccia pipes and numerous occurrences of calcitized evaporites indicate widespread hypogene speleogenesis throughout the entire Castile Formation. Although most cave and karst development within the Castile outcrop region appears to have hypogene origins, epigene processes are actively overprinting features, creating a complex speleogenetic evolution within the Castile Formation.
\end{abstract}

Keywords: hypogenic caves, epigenic overprint, speleogenesis, evaporites, geomorphology

Received 21 July 2007; Revised 16 October 2007; Accepted 8 November 2007

\section{INTRODUCTION}

Southeastern New Mexico and Far West Texas are well known internationally for the carbonate caves of the Guadalupe Mountains (e.g. Carlsbad Cavern, Lechuguilla Cave) (e.g. Hose \& Pisarowicz, 2000). However, extensive evaporite karst regions occur to the north, south and east of this region (Fig. 1), but they have remained largely underappreciated and understudied in karst science. The famous carbonate caves of the Guadalupe Mountains are developed in the Permian reef facies (Capitan Formation) and near backreef facies (Yates and Tansil Formations) of the Delaware Basin, while evaporite caves are developed in the contemporaneous far backreef facies (Artesia Group), as well as in subsequent basin filling evaporite facies (Castile Formation) and overlying units that covered the Permian Reef (Salado and Rustler Formations) during late

1 Department of Earth and Environmental Science, New Mexico Institute of Mining and

2 National Cave and Karst Research Institute, Carlsbad, New Mexico 88220, USA

3 Science Department, Carlsbad High School, Carlsbad, New Mexico 88220, USA
Permian (Fig. 2) (Scholle et al, 2004). Limited studies on specific caves or local karst regions have been conducted within the evaporite facies of the Permian Basin, including karst studies in the San Andres Formation (Forbes \& Nance, 1997) and Seven Rivers Formation (Stafford et al, 2007a; Land, 2006) of the Artesia Group, the Castile Formation (Sares, 1984; Nance, 1993), and the Salado and Rustler Formations (Hill, 1996). However, no studies have been conducted to evaluate the full range of cave and karst development within any of the evaporitic units of the region. Cave exploration has been conducted by the Gypsum Karst Project (GYPKAP) of the National Speleological Society throughout the evaporite karst regions of New Mexico (Eaton, 1987; Belski, 1992; Lee, 1996). Documentation of evaporite karst regions within Texas has been conducted by the Texas Speleological Survey (TSS) (e.g. Redell \& Fiesler, 1977). Although all of the evaporite facies of the region deserve comprehensive study, it is beyond the scope of a single study; therefore, this research focuses specifically on karst development in one evaporitic unit, the Castile Formation because it is the largest continuous outcrop of a single evaporite formation in the Permian Basin. This study is part of a 


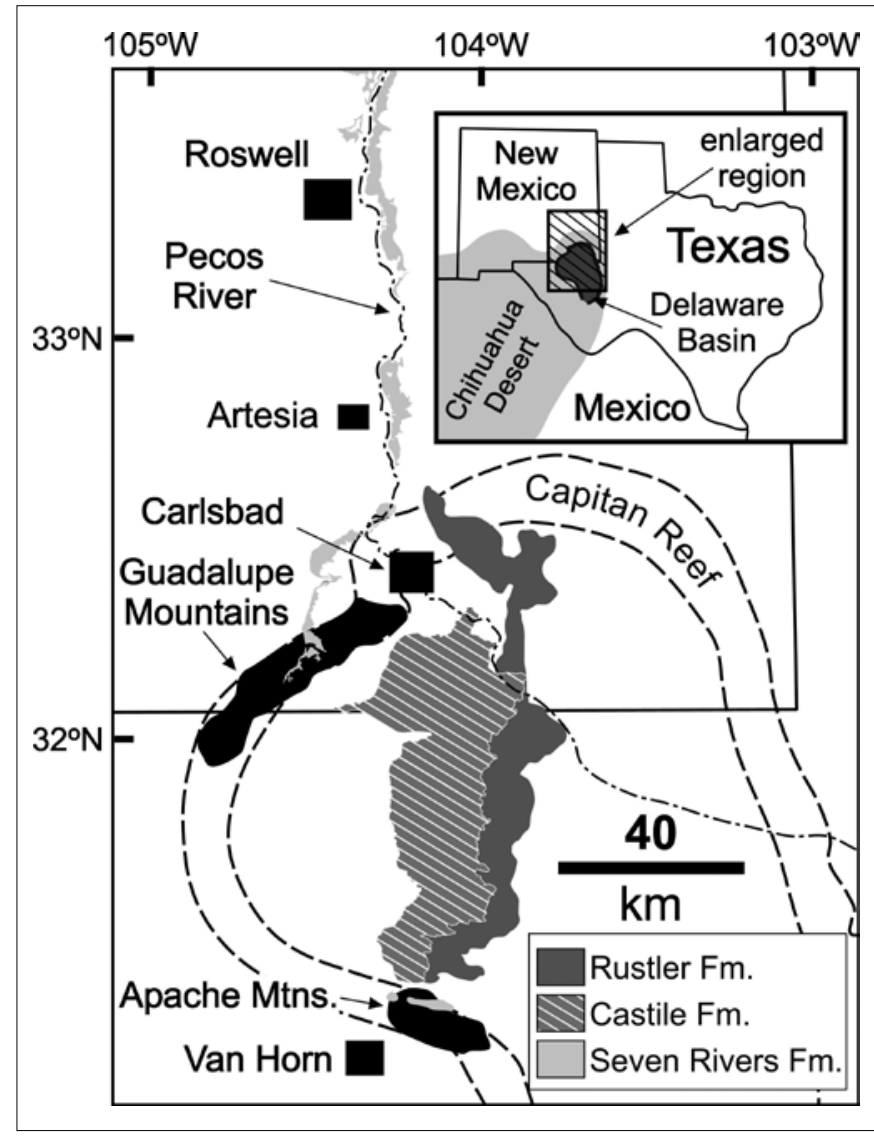

Fig. 1. Regional map showing major outcrops of Permian evaporite facies in southeastern New Mexico and far west Texas (Rustler, Castile, and Seven Rivers Formations). Hatched area delineates the Castile Formation outcrop region, the primary study region of this manuscript. The Capitan Reef, the reef facies of the Capitan Formation, delineates the margin of the Delaware Basin and forms the Guadalupe Mountains on the northwest and the Apache Mountains to the southwest, where it crops out at the surface. Inset box in upper right delineates the location of the enlarged area within Texas and New Mexico and the spatial extent of the Delaware Basin. (Adapted from Kelley, 1971 and Dietrich et al, 1995)

larger ongoing study to evaluate the regional speleogenetic evolution of the Delaware Basin, throughout southeastern New Mexico and far west Texas.

Because of the high solubility of evaporite rocks, dramatic karst landscapes can develop in them. The near linear solution kinetics of evaporites encourages the development of large sinks, incised arroyos (i.e. incised stream beds that experience high flow during flash flood events but remain dry the majority of the year), and caves that are laterally limited in epigene settings (Klimchouk, 2000a). Similarly, in hypogene settings steep fluid density gradients can be established in calcium sulfates, which create free convection cells that have the potential to dissolve significant volumes of void space (e.g. Anderson \& Kirkland, 1980; Kempe, 1996; Klimchouk, 2007). Whether speleogenesis is epigene or hypogene, the high solubility of evaporites enables the development of extensive karst much more rapidly in calcium sulfates (gypsum/anhydrite) than in carbonate rocks. In the United States, calcium sulfate rocks (gypsum and anhydrite) underlie $35-40 \%$ of the continental land surface (Johnson, 2002). However, most studies of karst in these evaporitic rocks of the United
States have focused primarily on risk assessment and avoidance associated with gypsum karst geohazards (e.g. Johnson \& Neal, 2003; Trzhtsinsky, 2002; Klimchouk \& Andrejchuk, 1996; Yauro \& Cooper, 2002). In contrast, gypsum karst in other regions of the world has been the focus of significant speleogenetic studies. The giant gypsum maze caves of the western Ukraine, developed in highly fractured, Miocene gypsum, have been studied extensively, providing the basis for much of the modern understanding of hypogenic speleogenesis (e.g. Klimchouk, 1996b, 2000b). Similarly, large, isolated voids, termed Schlotten, developed in the Permian gypsum of Germany have provided greater insight into hypogene processes in regions where little structural deformation of rocks has occurred (Kempe, 1996). In contrast, extensive studies of epigene karst have been conducted in Spain (e.g. Calaforra et al, 2002; Calaforra $\&$ Pulido-Bosch, 1996) and Italy (e.g. Sauro, 1996), where gypsum karst forms dramatic landscapes consisting of extensive solutional doline fields and abundant small caves.

Cave and karst development within the Castile Formation is extensive. Within the Castile outcrop area of the western Delaware Basin (Eddy County, New Mexico and Culberson County, Texas), surficial karren, sinkholes and associated caves dominate the landscape (Stafford, 2006; Stafford et al., 2006, 2007b). Throughout the entire Delaware Basin, evidence of subsurface dissolution through hypogene speleogenesis occurs in the Castile Formation as evidenced by the widespread distribution of collapse structures and cross-formational brecciation (Anderson \& Kirkland, 1980). Here we will systematically discuss the different karst manifestations observed within the Castile Formation (surficial forms, epigene caves, hypogene caves, and intrastratal breccias) with representative examples provided. The Castile Formation offers a unique opportunity to study karst development within an entire formation because it was deposited as a basinfilling sequence that isolated deposition to a restricted region which has subsequently experienced the same tectonic history throughout.

\section{STUDY AREA}

The Castile Formation crops out over approximately $1800 \mathrm{~km}^{2}(\sim 12-40 \mathrm{~km}$ wide from east to west and $\sim 90 \mathrm{~km}$ long from north to south) in the western Delaware Basin (Fig. 1) (Hill, 1996). The outcrop region is bounded on the north by the Guadalupe Mountains, on the south by the Apache Mountains, on the west by the dissolution front of the Castile Formation and on the east by outcrops of the Rustler Formation where the Castile Formation dips into the subsurface (Bachman, 1984; Stafford et al., 2007b). The study area is located on the northern edge of the Chihuahuan Desert where annual precipitation averages $26.7 \mathrm{~cm}$ and occurs primarily as intense, short duration monsoonal storm events during late summer (Sares, 1984). Annual temperature averages $17.3^{\circ} \mathrm{C}$, with an average minimum and maximum of $9.2^{\circ} \mathrm{C}$ and $25.2^{\circ} \mathrm{C}$, respectively.

The Castile Formation was deposited during the 
late Permian, subsequent to deposition of the Capitan Formation (Scholle et al, 2004), which forms the bounding reef margin of the Delaware Basin (Fig. 2). Castile evaporites represent deep-water deposits within a stratified, brine-filled basin (Kendall \& Harwood, 1989), bounded below by clastic deposits of the Bell Canyon Formation. Castile evaporites filled the Delaware Basin during deposition and were subsequently covered by Permian evaporites of the Salado and Rustler Formations (Fig. 2) (Kelley, 1971).

The Castile Formation is classically defined as laminated to massive anhydrite / gypsum, interbedded with halite (Dietrich et al, 1995), where laminated portions represent seasonal variations in basin salinity during deposition. Because of the extremely high solubility of halite, it does not crop out at the surface within the study area and has been completely removed in the subsurface by intrastratal dissolution within the Castile outcrop region. However, four zones of halite interbeds have been documented within the eastern Delaware Basin, which directly correlate with intrastratal breccia zones in the western Delaware

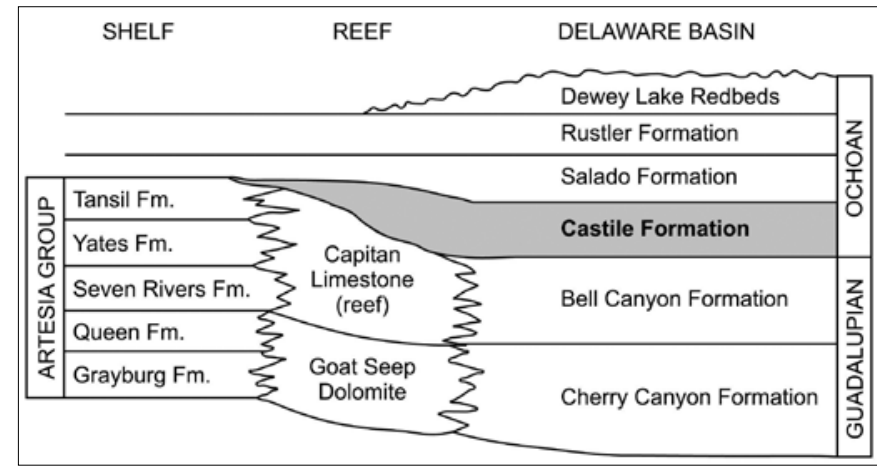

Fig. 2. Diagram of Permian formations associated with the Guadalupe Mountains, including the shelf, reef and basin facies. Note the stratigraphic position of the Castile Formation (shaded area) discussed throughout this study (adapted from Scholle et al, 2004).
Basin. Thin calcite laminae were deposited during less saline, wetter climates and gypsum / anhydrite laminae were deposited during more saline, dryer climatic periods (Anderson etal, 1972). However, diagenetic alteration since deposition has produced additional variability in lithologic texture, such that laminated, massive, nodular and tabular (selenite) fabrics, as well as calcitized evaporites, commonly occur (Machel \& Burton, 1991, Stafford et al., 2007b). Most fabric alteration is the product of gypsum / anhydrite mineral conversion associated with hydration / dehydration processes during burial and exposure (Dean et al, 1975). Mineral conversion also induces brittle deformation related to mineral conversion associated with hydration and dehydration, resulting in endokinetic fissuring (Klimchouk \& Andrejchuk, 1996). Calcitization of evaporites is widespread, where sulfate reducing bacteria in the presence of ascending hydrocarbons have reduced calcium sulfates, enabling the replacement of calcium sulfates with calcium carbonates, often termed biogenic limestone, as well as the byproduct hydrogen sulfide (Kirkland \& Evans, 1976). Oxidation of hydrogen sulfide commonly produces native sulfur, which has formed several economic sulfur bodies within the region (Hentz \& Henry, 1989).

In addition to diagenetic sulfate alteration within the Castile Formation, the region has experienced some tectonic deformation. Compressional tectonism in the Triassic and Laramide (late Cretaceous to mid-Tertiary) produced regional tilting to the northeast, broad anticlinal flexures and fracturing with minimal offsets within southeastern New Mexico and far West Texas (Dickenson, 1981). The far western edge of the Delaware Basin has been down-dropped along the far eastern margin of Basin and Range extensional block faulting in the mid-Tertiary; however, within the remaining portion of the Delaware Basin the effects are limited to nearvertical joints (Horak, 1985). As a result of the tectonic history of the region, Castile evaporites currently dip 3

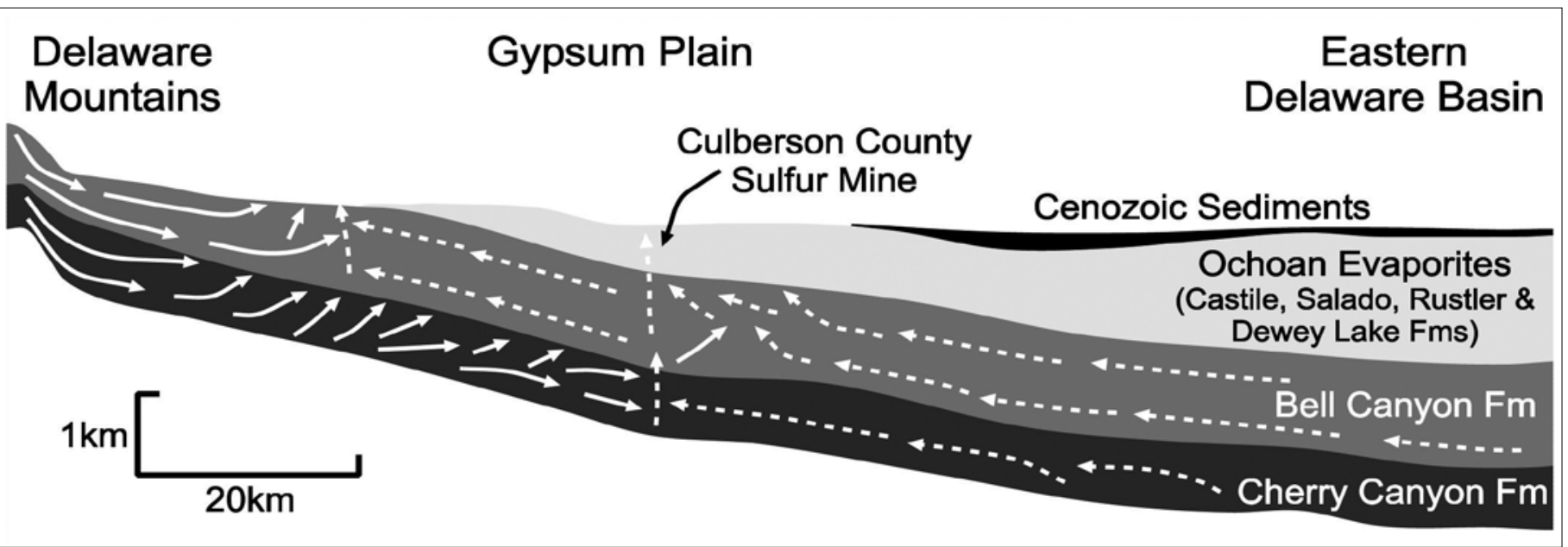

Fig. 3. Simplified paleohydrology of the Castile Formation showing the uplifted Delaware Mountains to the west and the interior of the Delaware Basin to the east where the Castile Formation is completely buried in the subsurface (adapted from Lee \& Williams, 2000). Solid white arrows depict meteoric waters recharged into the Bell Canyon and Cherry Canyon Formations to the west of the Castile Formation outcrop area. Dashed arrows depict ascending basinal fluids and hydrocarbons that have migrated up dip through the Delaware Basin. Both oxic meteoric waters and anoxic basinal waters migrate vertically through the overlying Castile Formation resulting in the formation of hypogene caves and calcitization of evaporites with emplacement of secondary native sulfur. As surface denudation continues to the east, oxic hypogene fluids replace anoxic hypogene fluids, which further enhance hypogene dissolution and can oxidize native sulfur in calcitized regions. As surface denudation continues to the east, fluid confinement is breached and epigene processes begin overprinting previously established hypogene flow paths. 
to 5 degrees to the northeast (Fig. 3), where they reach a maximum of 480 meters in the subsurface (Hill, 1996) and gradually thin to several meters on the far western edge of the Castile outcrop region where surface denudation has been the greatest. Tectonic fissuring has produced abundant conjugate joint sets oriented at $\sim \mathrm{N} 75^{\circ} \mathrm{E}$ and $\sim \mathrm{N} 15^{\circ} \mathrm{W}$ (Nance, 1993).

\section{CASTILE KARST}

Karst development within the Castile outcrop region is diverse and widespread. Stafford et al (2007b) reported approximately 10,000 surficial karst features (i.e. sinkholes and caves) for the entire Castile outcrop region by coupling field mapping and GIS techniques. They pointed out that feature distribution was highly clustered (Fig. 4) and suggested that this indicate that most karst development was associated with hypogene speleogenesis. Approximately $40 \%$ of the region exhibits effectively no karst development, while two small regions, each less than $10 \mathrm{~km}^{2}$, contain more than 40 caves or sinkholes per square kilometer (Fig. 4) (Stafford et al, 2007b). Karst development is most intense in the northwestern portion of the Castile outcrop region, but numerous clusters of significant karst development occur throughout the entire study area. In addition to sinkholes and caves, extensive karren is present

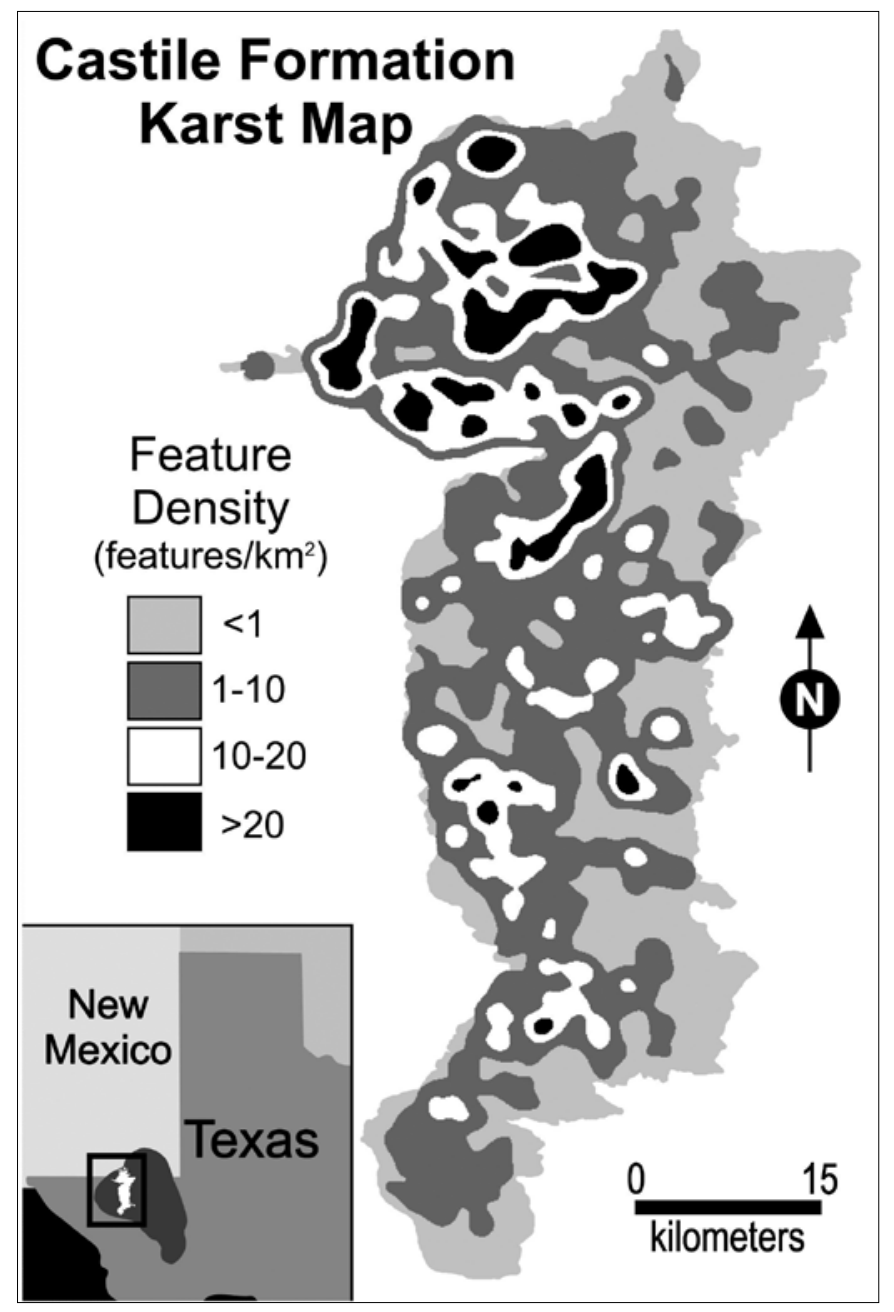

Fig. 4. Simplified karst feature distribution and density map of the Castile Formation outcrop region (adapted from Stafford et al, 2007b). Note the clustering pattern of denser karst regions shown in black. on exposed rock surfaces, as well as karstic breccias. Closed depressions are often filled with sediments, making it difficult to determine their speleogenetic origin, whether collapse of hypogenic or epigenic voids or incised from epigene processes (e.g. Ford \& Williams, 2007; White, 1988). The study of individual caves within the region indicates that both hypogene and epigene karst phenomena are widespread.

Fifty randomly selected $1 \mathrm{~km}^{2}$ regions were physically mapped, including characterization of karst features, throughout the $1,800 \mathrm{~km}^{2}$ study area (Stafford et al, 2007b). Mapped sites were randomly selected using GIS (Geographic Information System) in order to avoid any human biases that could be introduced into field studies and to enable a more accurate representation of total karst development within the region, not just regions containing abundant karst features. Field mapping identified 196 open sinkholes with associated caves and 139 filled sinkholes; however, only 102 of the open sinkholes included associated caves large enough to be entered by humans. Time constraints limited cave mapping to a representative sample of 32 previously undocumented caves which were chosen to demonstrate the diversity of cave development within the Castile Formation. These newly surveyed caves were subsequently used as the primary database for evaluation of Castile karst development because they were mapped with the same level of accuracy, while previously mapped features were surveyed by a wide range of individuals with varying levels of detail and accuracy (e.g. Redell \& Feisler, 1977; Eaton, 1987; Belski, 1992; Lee, 1996). In order to confirm observations made in newly documented features in this study, several previously known and mapped caves were visited for comparison.

Analysis of this database and previous studies (e.g. Redell \& Feisler, 1977; Lee, 1996) indicates that caves and karst in Castile evaporites are developed in a wide range of lithologic fabrics and do not appear to be associated with any specific gypsum fabric. Most caves are developed in laminated or massive gypsum, which directly corresponds to the relative abundance of these fabrics. Many caves are hosted in the surficial gypsite deposits, which are often developed at the interface of the gypsic soils and the underlying bedrock. Gypsite is composed of fine-grained aeolian particles (primarily clay and silt), residual insoluble material derived from solution of underlying bedrock and precipitated secondary gypsum which binds sediment and creates a poorly consolidated soil (Cantón et al, 2003). Caves have been observed within tabular (selenite) and nodular gypsum as well as calcitized evaporites, but more commonly, karst development is observed within these fabrics when they are transected within portions of larger caves primarily developed in laminated or massive fabrics. However, caves and karst appear to develop largely independently of the local gypsum fabric. Instead, karst development appears to be primarily related to the local and regional geologic and hydrologic regime with only minor variations in passage wall morphology and surficial geomorphology associated with local variations in lithologic fabric.

Caves within the Castile Formation are usually developed along regions of structural deformation, both 
ductile and brittle, which is consistent with observations made within other evaporite karst regions of the world (Klimchouk et al, 1996; Johnson \& Neal, 2003). Because of the low permeability of gypsum and anhydrite, fractures and bedding partings are crucial for enabling fluids to migrate through sulfate rocks promoting the development of dissolutional conduits (Klimchouk, 1996a). Most individual passages within the Castile Formation are developed either along joints (Fig. 5A,B) with no apparent offset or other fractures with minimal offset (Fig. 5C). These guiding fractures are most easily recognized in epigene caves (Fig. 5A), but are also commonly observed in major passages in hypogene caves (Fig. 5B,C). In regions where folding has occurred, individual passages are frequently developed along the axis of anticlines (Fig. $5 \mathrm{D}, \mathrm{E})$, where compressional forces have produced smallscale bedrock partings.

Previous studies on cave development have used analyses of passage orientations as a proxy for determining regional structural deformation, especially in regions where vegetation or surficial mantling obscures bedrock (Nelson, 1991; Barlow \& Ogden, 1992). Because gypsum weathers easily and often forms hydration crusts that significantly

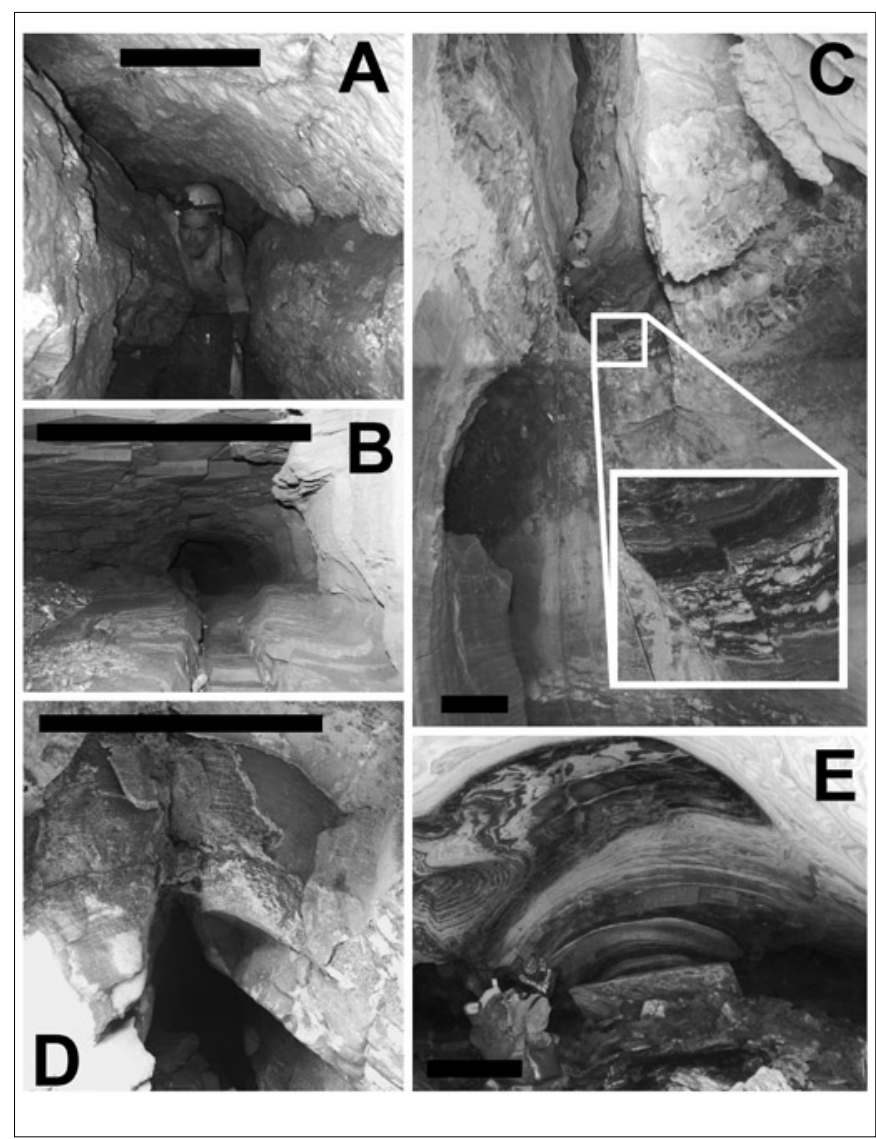

Fig. 5. Brittle and ductile structural controls on gypsum karst development within the Castile Formation. Black scale bars are $\sim 0.5$ $m$ long. A) Fracture controlled passage in an epigene cave (Zombie Cave, Eddy Co., New Mexico); B) Fracture controlled passage in a hypogene cave (Dead Bunny Hole, Culberson Co., Texas); C) Fracture controlled passage in a hypogene cave with inset showing $\sim 10 \mathrm{~cm}$ of vertical offset along fracture (Crystal Cave, Culberson Co., New Mexico); D) Epigene cave developed along an anticline fold axis (Dead East Cave, Culberson Co., Texas); E) Hypogene cave development along an anticline fold axis (Dead Bunny Hole, Culberson Co., Texas). distort surficial rock exposures, a similar study was conducted using the caves that were mapped during this study. Of the 32 caves mapped, 4 are developed in surficial gypsite; therefore, these caves were not included in analyses because they are not developed within bedrock and did not show any definitive evidence of structural control. In order to apply greater significance to larger or longer passages, the passage orientations were weighted according to passage length. Each five meter segment of passage was considered as a separate orientation measurement (e.g. a 15 meter long passage oriented at $35^{\circ}$ azimuth is counted as three separate orientation measurements of $35^{\circ}$ ) (Stafford et al, 2005). Passages less than 2.5 meters long were not included in analyses. Because cave maps are oriented according to magnetic north, passage orientation measurements were corrected for local magnetic declination, which ranges from $7^{\circ} 20^{\prime} \mathrm{E}$ on the northern edge of the study area to $8^{\circ} 30^{\prime} \mathrm{E}$ on the southern edge of the study area (Hill, 1996).

Passage orientation analyses (Fig. 6) indicate a wide range of fracture orientations associated with cave development. One dominant orientation trend of $\sim \mathrm{N}^{\circ} 0^{\circ} \mathrm{W}$ and two secondary orientation trends of $\sim \mathrm{N} 10^{\circ} \mathrm{W}$ and $\sim \mathrm{N} 45^{\circ} \mathrm{E}$ are present within the data, which probably represent tectonic deformation within the region. Only the $\mathrm{N} 10^{\circ} \mathrm{W}$ trend of these orientations is similar to the tectonic fissuring reported by Nance (1993). Epigene cave passages and most hypogene cave passages show direct correlation with fractures in the field, but the complexity of total passage orientations suggests that many of these are not tectonic fractures. Instead, it is likely that many of the fracture controlled passages are developed along endokinetic fissures that have been induced through mineral conversion, while the dominant passage orientations likely

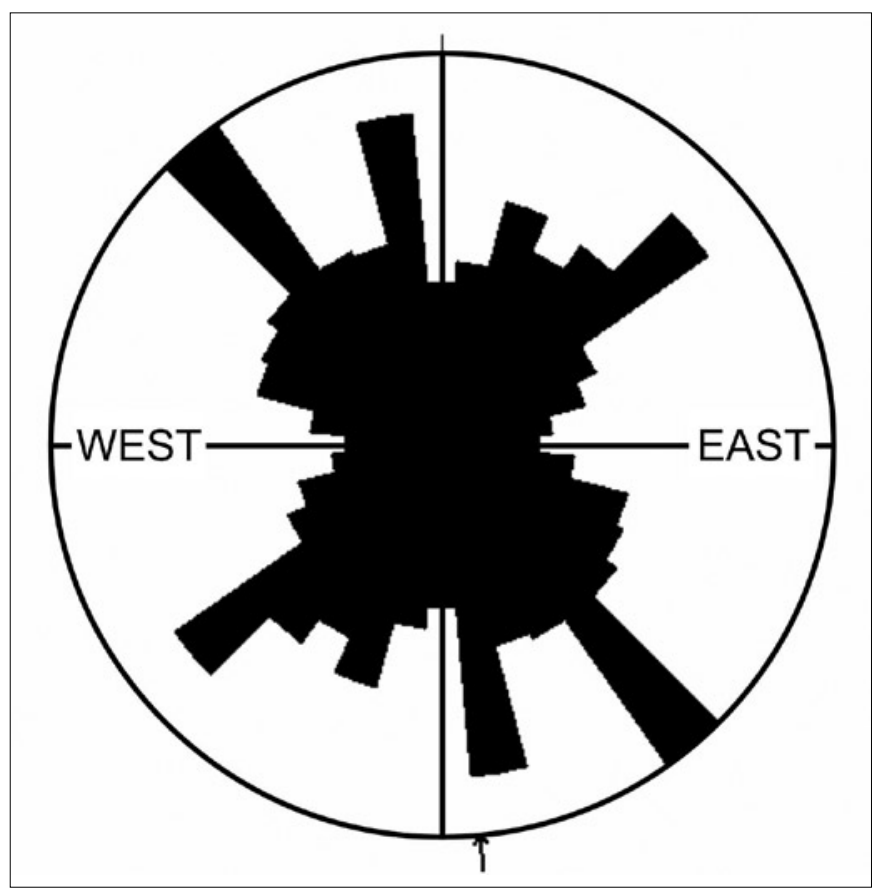

Fig. 6. Rose diagram showing cave passage orientations from 28 caves surveyed within the Castile outcrop area during this study ( $N=556$ passage segments). Note the three dominant passage orientations $\left(\sim \mathrm{N} 40^{\circ} \mathrm{W}, \sim \mathrm{N} 45^{\circ} \mathrm{E}\right.$ and $\left.\sim \mathrm{N} 10^{\circ} \mathrm{W}\right)$, which likely represent major tectonic fissuring within the western Delaware Basin. 
represent major structural deformation within the region. Hypogenic caves develop within a non-competitive, uniform hydrologic regime where all bedrock heterogeneities are exploited equally; therefore, we expect that the complexity in evaluating regional tectonic deformation based on analyses including hypogene caves will inherently increase compared to cave development in purely epigene settings. Bedrock heterogeneities include fractures, as well as minor variations in rock permeability, porosity and composition, which result from the depositional and diagenetic history of the region.

Within the study area, karst manifestations occur in four primary forms: 1) surficial karst, 2) epigene caves, 3) hypogene caves, and 4) intrastratal brecciation. There is significant overlap between each of the individual forms due to multiple formational episodes and varied genetic origins of speleogenesis within the Castile Formation. The following sections systematically discuss each of the primary types of karst manifestation.

\section{Surficial karst}

Karst development within the Castile outcrop region has abundant surficial manifestations, ranging from sinkholes to karren and surficial precipitates. Approximately $8 \%\left(138 \mathrm{~km}^{2}\right)$ of the outcrop region is composed of exposed bedrock. Most exposed bedrock is covered with a thin gypsum crust; however, bedrock regions that are not covered by crust generally exhibit extensive karren. Throughout the entire, $1,800 \mathrm{~km}^{2}$ outcrop region, sinkholes or closed depressions are abundant, including both open and filled forms.

Sinks (i.e. sinkholes or closed depressions) are the dominant karst geomorphic manifestation throughout the Castile outcrop region; however, their geomorphic expression is varied. Sinkholes appear as both filled and open forms, where open sinkholes are connected directly to solutional conduits. Sinkholes, in general, form by two basic mechanisms, solutional incision of descending waters or collapse of upward stoping subsurface voids (e.g. Ford \& Williams, 2007; White, 1988). Incised sinkholes generally exhibit lateral elongation and often have several, well-developed arroyos that converge towards a central drain. Collapse sinks tend to be expressed as near-circular or elliptical features with steep walls; however, sink morphology is often obscured because of sediment infilling. Because collapse sinks tend to be nearcircular and solutional sinks tend to be elongate (Ford \& Williams, 1989; White, 1988), analyses of sink width to length ratios can be used to proxy for predicting sink origin when surficial expression is subdued by sediment filling. However, this is only an approximation because significant overprinting of collapse sinks by surficial processes can modify original morphology. Therefore, sinks with a width to length ratio of greater than 0.5 are elliptical or near-circular, hence these features likely represent collapse sinks, while features with a width to length ratio less than 0.5 likely represent solutional sinks or collapse sinks that have been heavily overprinted by surficial processes. Based on width to length analyses of 335 sinks identified during field mapping, 55\% of the features are the result of collapse (Fig. 7). It is likely that most of the remaining $45 \%$ of features are solutional sinks, but it is probable that many of these are collapse features that have been overprinted by solutional incision from meteoric processes. Each of the sinkholes used in this analysis was visually inspected in the field. Elliptical sinks observed in the field often contained large collapse blocks and appeared to be the result of subsidence collapse, while elongate sinks were deeply incised and showed clear evidence of significant solutional enlargement.

Solutional karren is well-developed on exposed rock surfaces and exhibits a wide-range of morphological forms. On near-vertical rock
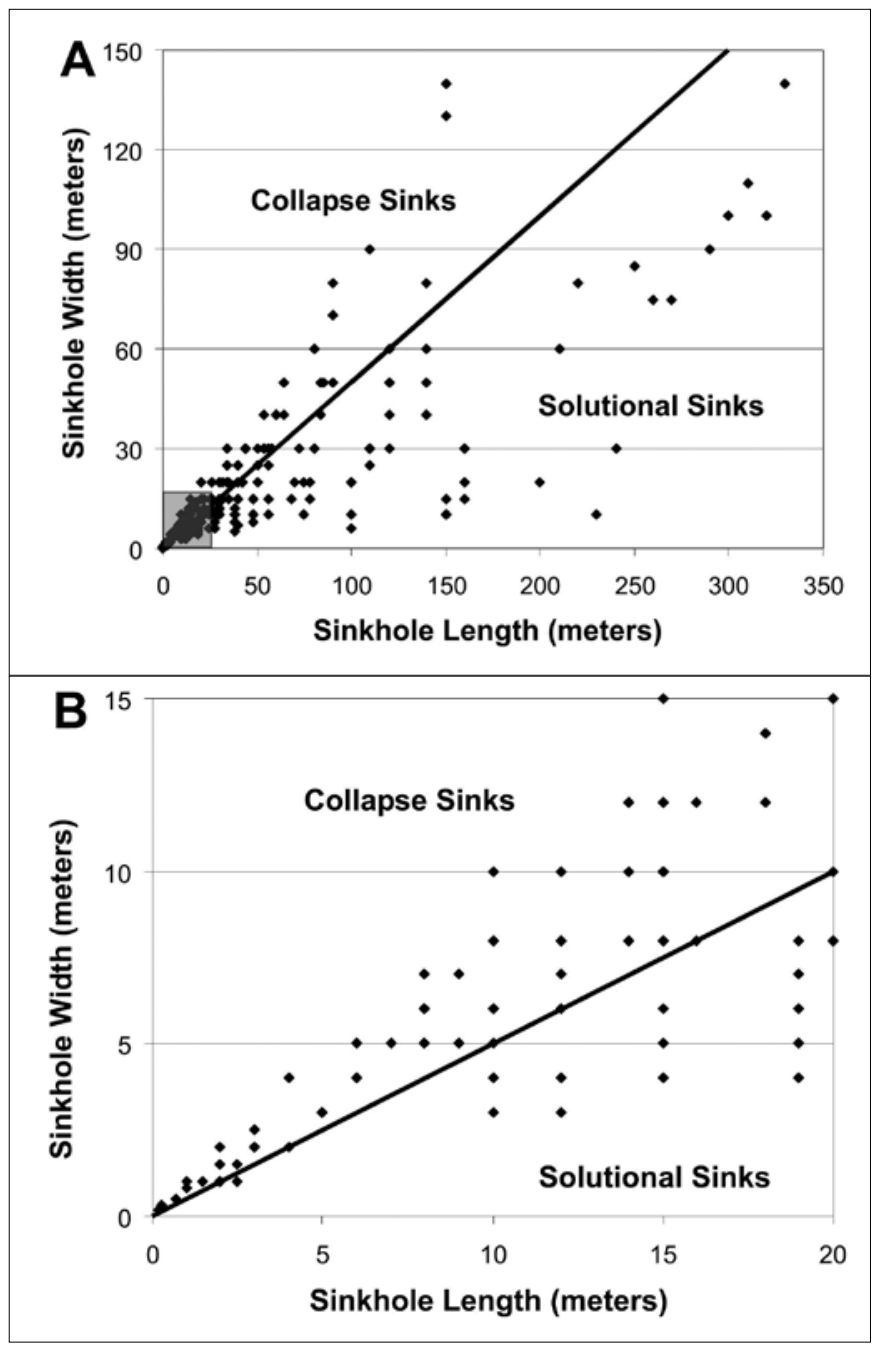

Fig. 7. Plots comparing length to width of sinkholes identified in the field within the Castile outcrop region. Diamonds represent sinkhole length/width while the solid line represents sinkhole length/width = 2. Features that plot above and to the left of this line are interpreted as collapse sinks, while features that plot below and to the right are interpreted as solutional sinks. A) Composite plot showing the 335 individual sinkholes studied in the field, which gives the impression that sinkholes are primarily solution; however, $55 \%$ of sinks are interpreted as collapse features because many collapse sinks are less than five meters wide. B) Enlarged view of shaded area in Fig. 7A showing that a many of the collapse sinks are small features that are not easily recognized in a plot of the entire data set. Observations in the field were consistent with interpretation of sinkhole origin basin on length to width analyses. . 
surfaces, deeply incised rillenkarren forms decimeter to meter long solutional flutes with centimeter-scale widths and depths (Fig. 8A). On moderately inclined surfaces, rillenkarren are less-developed, generally forming shorter solution flutes that commonly converge in the down slope direction, creating complex, small-scale, dendritic channel networks (Fig. 8B). On near horizontal surfaces, spitzkarren and kamenitzas are observed. Spitzkarren occurs as centimeter scale karst pinnacles (Fig. 8C) on gently sloping surfaces that generally converge with rillenkarren where surface slope increases. Kamenitzas or solution pans form shallow, depressions floored with microbial mats on level surfaces, with depths up to several decimeters and widths ranging from decimeters to meters. In addition to traditional karren forms, unique karren are observed in the region. Where selenite is exposed at the surface, blade-like karren is formed (Fig 8D) and microkarren forms through preferential dissolution of individual crystals within selenite masses.

On most exposed gypsum bedrock surfaces a thin, millimeter to centimeter crust develops that is largely devoid of macro flora (Fig. 8E). The crusts form as a result of dissolution of the uppermost, exposed bedrock producing saturated fluids that subsequently precipitate a highly porous crust. This occurs because the lack of confinement does not constrict crystal growth (Cantón et al, 2003; Macaluso \& Sauro, 1996). Although macroflora is uncommon, abundant

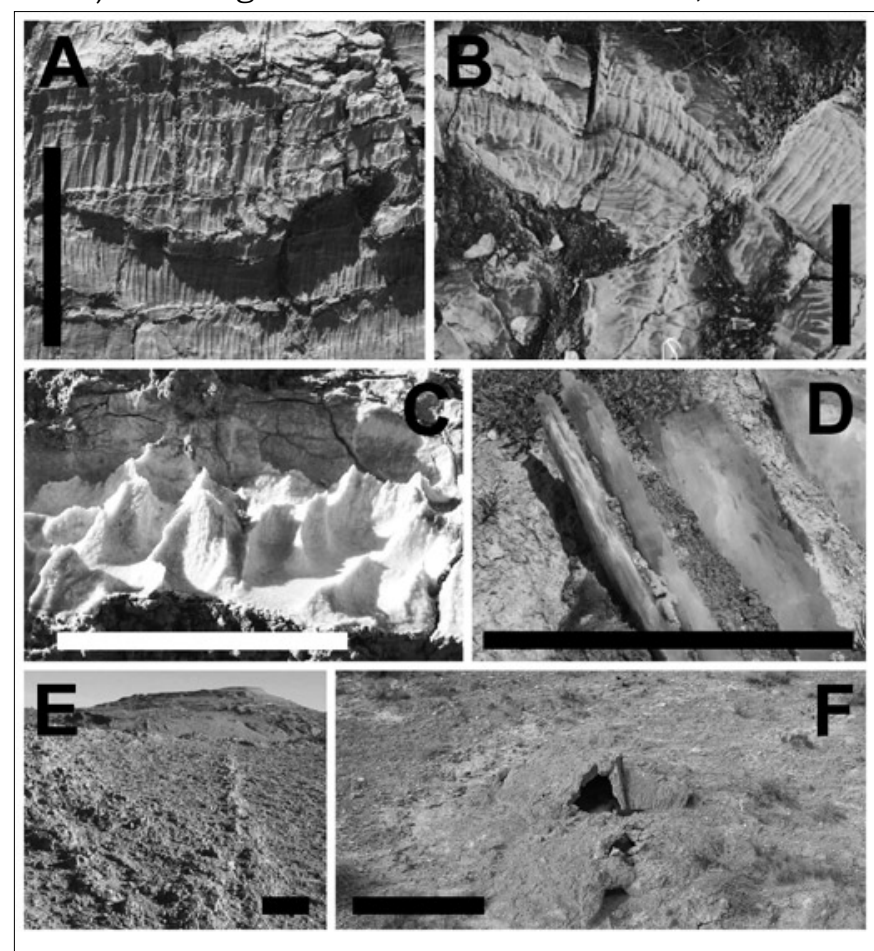

Fig. 8. Surficial karst manifestations within the Castile outcrop region. Black scale bars are $\sim 50 \mathrm{~cm}$ long. White scale bar is $\sim 20 \mathrm{~cm}$ long. A) Incised rillenkarren on vertical surfaces; B) Complex rillenkarren on moderately inclined surfaces $\left(\sim 30^{\circ}\right)$; C) Spitzkarren developed on near-horizontal surfaces; D) Blade-like karren developed on exposed tabular (selenite) gypsum surfaces; E) Extensive gypsum crusts developed on large bedrock exposures; F) Domal tumuli forming small hollow surface cavities. lichens and microbial colonies are present on crust surfaces, which likely contribute to crust formation by retaining saturated fluids on exposed surfaces instead of allowing them to be removed by surface runoff. In addition to crusts, tumuli or gypsum blister caves commonly develop (Fig. 8F). Tumuli form hollow, domed structures from gypsum precipitation in areas where crystal growth is laterally confined and results in surficial buckling (Calaforra \& PulidoBosch, 1999). Although neither crusts nor tumuli are classic surficial karst manifestations in carbonate terrains, they are common features in gypsic terrains (Macaluso \& Sauro, 1996)

\section{Epigene caves}

Epigene caves are widespread within the Castile outcrop region, but primarily occur as isolated features associated with well-developed, solutional closed depressions. Because of the high solubility of calcium sulfate, dissolution occurs rapidly in response to the modern environment. The near-linear solution kinetics of gypsum encourages greater epigenic dissolution at the surface proximal to the source of meteoric waters. This often forms large, incised sinkholes connected to small solution conduits (Klimchouk, 2000a). Epigene caves in the study area have been identified in laminated, massive, nodular and tabular (selenite) gypsum fabrics as well as in surficial gypsite deposits. All epigene caves studied contain well-developed, small-scale scallops on walls, ceiling and floors, indicating that epigene caves transmit significant volumes of water at high velocities (White, 1988), most likely during intense, monsoonal precipitation events.

Although it is often impossible to definitively determine the origin of solution conduits that are too small to be entered by cavers, it is logical to assume that most small, solutional sinkhole drains in the study area are the result of epigene speleogenesis, which is consistent with solution kinetics of calcium sulfate (Klimchouk, 2000a). Where dissolution has been sufficient to create epigenic caves, they are generally limited laterally and form shallow groundwater recharge features. In these cases, the average passage aperture rapidly decreases away from insurgences, where the most intense dissolution occurs at the land surface and first few tens of meters in the subsurface (Fig. 9). Beyond this, descending fluids are likely close to saturation and unable to dissolve additional bedrock (Klimchouk, 1996a; Jeschke et al, 2001). Occasionally, epigenic caves form shallow subsurface bypass features connecting points of differing elevation at the land surface and do not exhibit the typical passage aperture decrease. This may be the result of waters passing directly through these features without reaching complete saturation (Stafford et al, 2006).

Zombie Cave is one of the largest epigenic caves identified within the Castile Formation, with a 43 meter surveyed length and depth of 3 meters (Fig. 10A). It is developed in laminated gypsum, but the characteristics it exhibits are also typical of all observed epigenic 


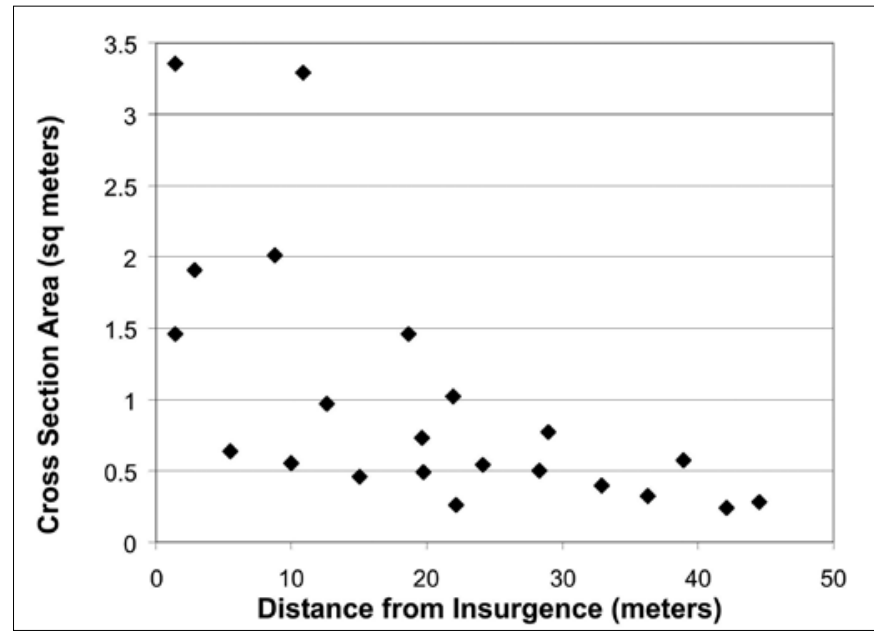

Fig. 9. Plot showing cave passage cross-sectional area compared to distance from cave insurgence for five epigene caves (Cave of the Room, Dead East Cave, Lightening Cave, White Centipede Cave, and Zombie Cave) surveyed during this study in laminated and massive gypsum within Castile outcrop region. Note the rapid passage aperture decrease away from the insurgences as a result of the high solution kinetics of calcium sulfate.

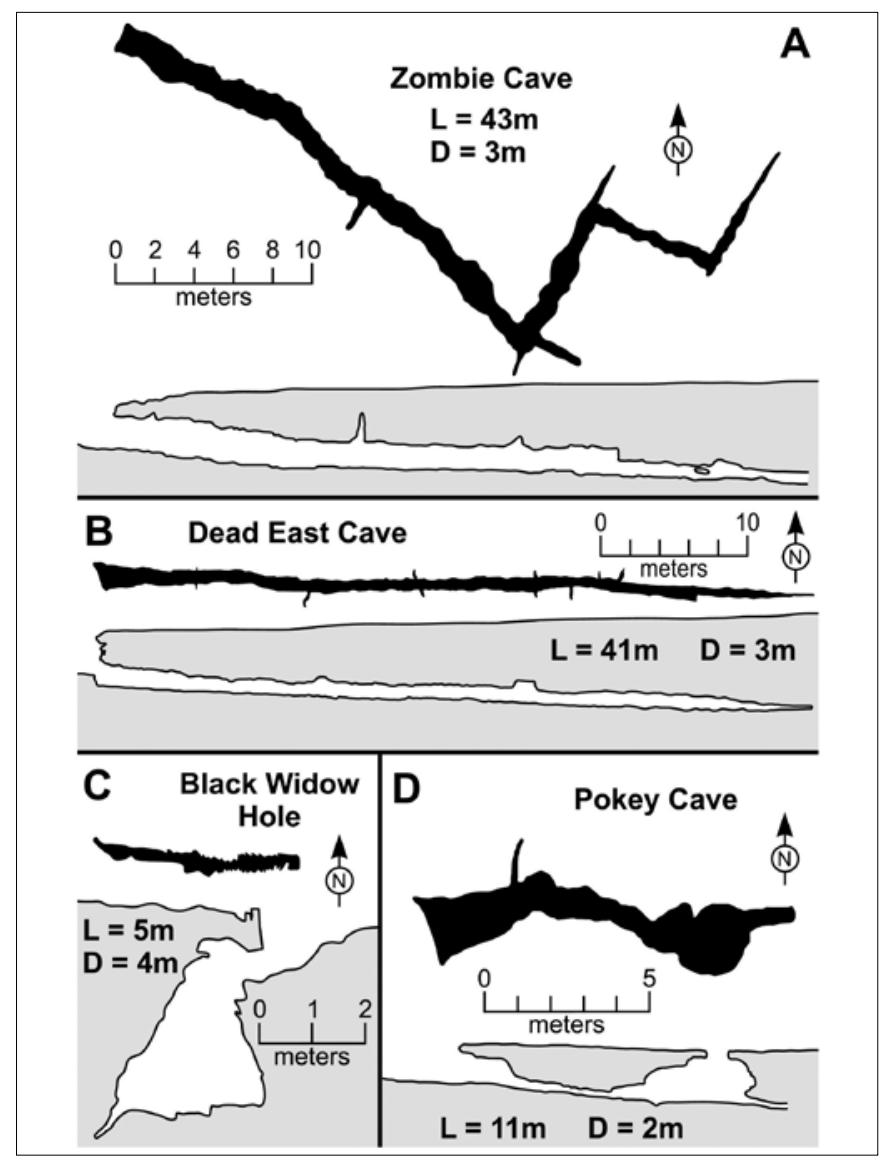

Fig. 10. Simplified maps of representative epigene caves surveyed during this study in the Castile Formation, including plan view (solid black) and profile (gray outline) views. Note that "L" refers to surveyed length and "D" refers to surveyed depth on individual maps. A) Zombie Cave is developed along well-defined fractures (Eddy Co., New Mexico); B) Dead east Cave is developed along the fold axis of an anticline (Culberson Co., Texas); C) Black Widow Hole is developed in tabular (selenite) gypsum (Culberson Co., Texas); D) Pokey Cave is developed in gypsite near the contact with gypsum bedrock (Culberson Co., Texas). Note that all north arrows indicate magnetic north. At the time of survey, Fall 2006, magnetic declination was $\sim 8^{\circ}$ eas caves found either in laminated, massive or nodular gypsum. The cave is developed along two distinct joint sets (Fig. 5A) that intersect at acute angles, with the primary solutional conduit descending gently into the subsurface, forming a branchwork cave pattern. Passage aperture decreases consistently away from the insurgence until it becomes too small to be humanly passable (Fig. 10A). Throughout, several small infeeders converge along fractures that intersect the main conduit at various angles, which has probably enabled significant solutional enlargement to continue over greater distances than generally observed in epigenic caves within the Castile Formation. Although most observed epigenic caves in bedrock are laterally limited with development along joint sets, occasionally epigenic caves develop along the fold axis of anticlines where rock compression has produced fractures along the fold axis (Fig. 5D), as is seen in Dead East Cave (Fig. 10B). Epigene caves that have formed along folds are generally linear features consisting of a single main conduit, which exhibits minimal convergence from secondary infeeder passages.

Epigene caves developed in tabular gypsum (selenite) exhibit similar characteristics with those developed in other gypsum fabrics. These caves are the least common type of epigenic cave, which is directly related to the limited areas where selenite is exposed at the land surface. They are small and laterally limited, similar to other epigenic caves, but cave development is controlled by the inherent selenite crystal structure (Fig. 11A), where partings between large tabular crystals provide preferential flow paths for solutional enlargement. Passage configuration and wall morphology directly reflect changes in crystal orientation and intersection, instead of exhibiting solutional control related to structural deformation. Caves developed in selenite demonstrate well the critical role of bedrock partings, whether fractures, bedding or individual crystal partings, for epigene solutional development in gypsum. Black Widow Hole (Fig. 10C) represents a typical epigene cave in selenite, where the solutional passage is oriented along crystal faces, descending steeply into the subsurface where it rapidly becomes too small for human exploration.

In surficial gypsite deposits (i.e. gypsic soils), epigene caves are common where they frequently develop along the contact with underlying gypsum bedrock. Although gypsite is a surficial mantling within the study area and not actually bedrock of the Castile Formation, cave development within surficial deposits and underlying bedrock appears related. Most epigene gypsite caves are small, laterally limited and appear largely ephemeral. Many contain several collapse entrances connected in series, where dissolution of secondary gypsum cements has enabled suffusion of insoluble soil components (Fig. 10D, 11B). Generally gypsite caves become too small to be enterable or plugged with sediment within a few tens of meters of their insurgence. However, in rare occurrences epigene gypsite caves can connect directly to caves in gypsum bedrock, suggesting that the occurrence of gypsite caves is related to bedrock caves by providing preferential flow paths for descending waters. 


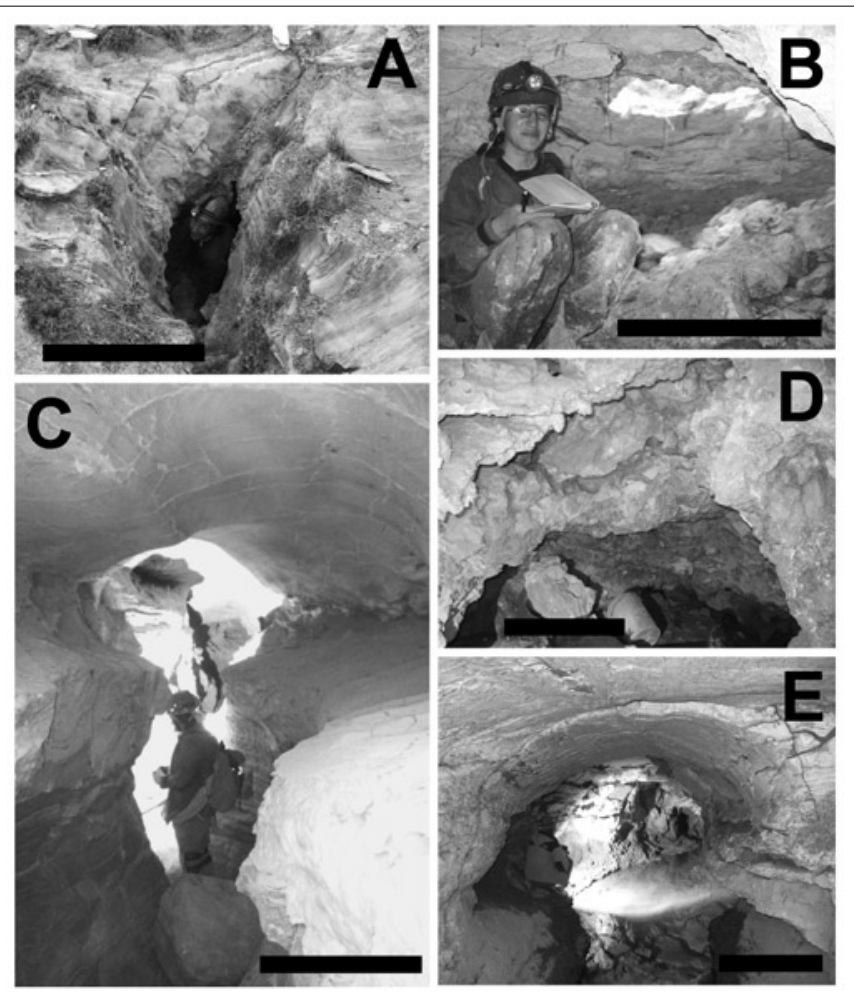

Fig. 11. Caves of the Castile Formation. Black scale bar are $\sim 1 \mathrm{~m}$ long. A) Black Widow Hole (Culberson Co., TX) is an epigene cave developed entirely in tabular (selenite) gypsum ; B) Pokey Cave (Culberson Co., TX) shows typical characteristics of gypsite caves including collapse regions through the thin gypsic soils; C) Epigene overprinting of hypogene conduits commonly produces passages with well-defined floor trenches and elliptical ceiling tubes (Crystal Cave, Culberson Co., TX); D) Isolated hypogene voids occur within calcitized masses (China Mine, Culberson Co., TX); E) Brantley Stream Cave (Culberson Co., TX) is one of several hydrologically active caves that exhibit hypogene morphologies and continuously discharge spring water through the year.

\section{Hypogene caves}

In contrast to epigene speleogenesis, which includes both epigene caves and most surficial karst manifestations, hypogene caves do not form with a direct connection to surface meteoric processes. Instead, hypogene speleogenesis is associated with dissolution from rising fluids that are delivered from undersaturated reservoirs beneath soluble rock units (Ford, 2006). In hypogenic systems, including both carbonate and evaporitic lithologies, dissolution is driven by a mixed convection hydrologic system, composed of components of both forced and free convection (Klimchouk, 2000c, 2007; Anderson \& Kirkland, 1980; Kohout et al, 1988). Forced convection is driven by differences in hydraulic potential across the region. Fluids from lower, pressurized aquifers or transmissive zones rise towards upper, lower hydraulic pressure regions, often the regional base level (Tóth, 1999). In order for pressurized (artesian) aquifers to develop, they must be confined or semi-confined such that pressure gradients can develop (Klimchouk, 2007). In the study area, the gypsum and anhydrite rocks of the Castile Formation act as leaky seals for the lower clastic Bell Canyon Formation (Fig. 3) (Lee $\&$ Williams, 2000). Here, fluid is directed vertically through fractures within the Castile evaporites. These fractures rarely cross the entire formation, but instead are composed of discontinuous fracture sets that limit cross-formational connectivity (Hill, 1996), which induces both vertical and horizontal flow between fractured regions (Klimchouk, 2007). Such limited connectivity results in sluggish flow driven by forced convection until breakthrough can be achieved, hence free convection becomes an important component of the dissolution process (Klimchouk, 2000b,c, 2007). Through free convection, aggressive waters are continuously delivered to the dissolution front through the simultaneous rising of less dense, undersaturated fluids and the sinking of more dense, saturated fluids (Anderson \& Kirkland, 1980; Klimchouk, 2007). Rising, undersaturated fluids are supplied by the lower transmissive zone, while descending, saturated fluids are removed down gradient through the same lower aquifer. Although the effects of speleogenesis can be observed in any type of soluble host rock (e.g. limestone, dolomite), they are particularly well pronounced in calcium sulfate rocks (i.e. gypsum / anhydrite) where high solubility enables the development of steep density gradients through free convection (Klimchouk, 2007; Anderson \& Kirkland, 1980).

Traditionally, hypogenic speleogenesis has been associated with multi-storey maze caves (Klimchouk, 1996, 2000b, 2000c) and isolated subsurface voids (Kempe, 1996). However, recent studies have shown that a diagnostic suite of morphological features observed in caves provides evidence of dissolution driven by a mixed convection system that is independent of cave patterns (Klimchouk, 2000b, 2003, 2007; Frumkin \& Fischhendler, 2005; Stafford et al, 2007a). This morphological suite of features includes: 1) risers, 2) outlets, and 3) half-tubes. Risers or feeders are cuspate wall and floor features (Fig. 12A,D) that indicate preferential flow paths that connect transmissive zones to soluble zones. This is where ascending, undersaturated fluids are delivered to soluble rock and saturated fluids are returned to transmissive zones. Outlets or cupolas are domal structures formed along ceilings (Fig. 12C,D) where ascending fluids move toward higher elevations and lower pressures (including upper transmissive zone and ultimately base level) through dissolution of soluble host rock. Half-tubes are developed on ceilings and walls where undersaturated fluids migrate from risers to outlets, forming concave, semicircular channels vertically along walls (Fig. 12D) or horizontally along the axis of ceiling passages (Fig. 12B). Although any of the features alone can be formed by various speleogenetic processes, when found together in composite morphologic suites, they provide unequivocal evidence of hypogene speleogenesis (Klimchouk, 2007; Stafford et al, 2007a).

Dense clusters of caves and sinkholes within the Castile outcrop region (Fig. 4) suggest that karst development is dominated by hypogene speleogenesis in the western Delaware Basin (Stafford et al, 2007b). Caves interpreted in the study 


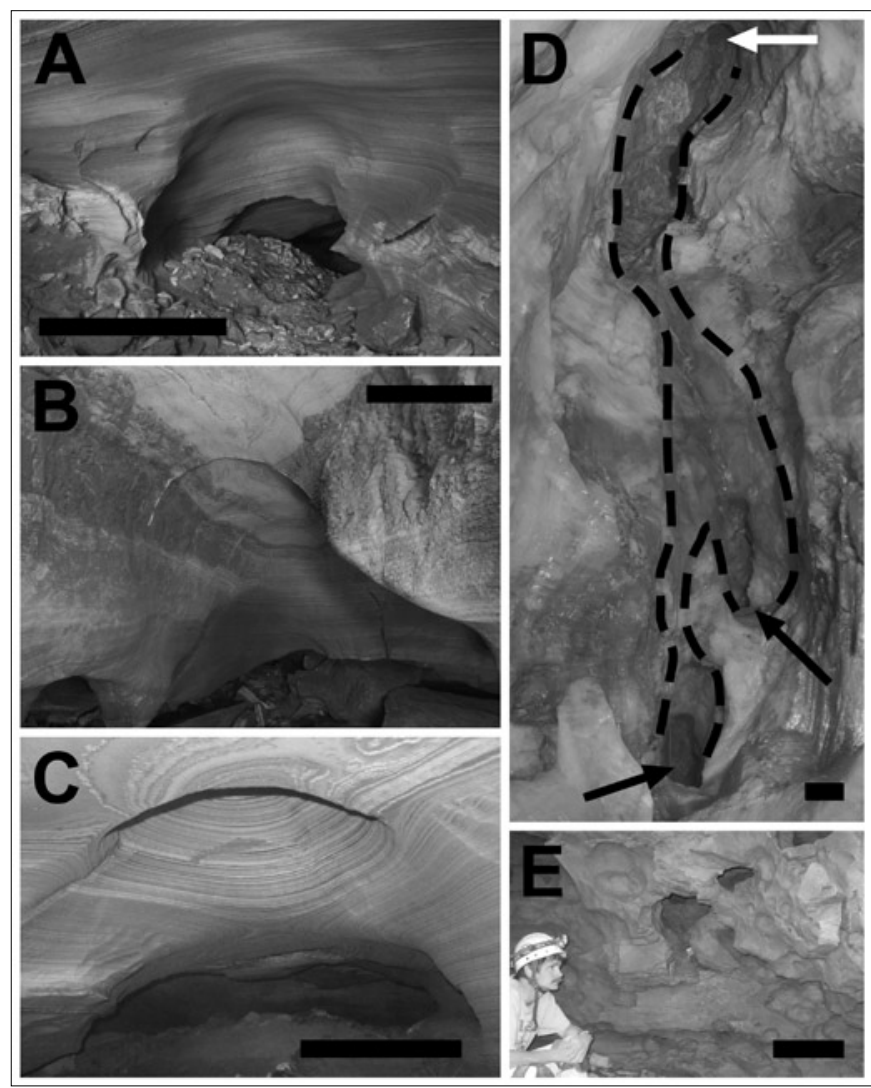

Fig. 12. Morphologic cave features indicative of hypogene speleogenesis within the Castile Formation. Black scale bars are $\sim 0.5 \mathrm{~m}$ long. A) Typical riser feature intersecting primary cave passage (Dead Bunny Hole, Culberson Co., TX); B) Well-developed ceiling half-tube (Dead Bunny Hole, Culberson Co., TX); C) Typical ceiling cupola or outlet in a series of domal ceiling features (Dead Bunny Hole, Culberson Co., TX); D) Complete morphologic suite of hypogene features developed in selenite: dashed lines delineate wall half-tubes, black arrows indicate separate risers and the white arrow indicates outlet cupola (Crystal Cave, Culberson Co., TX); E) Typical region of solutional boneyard morphology (Dead Bunny Hole, Culberson Co., TX).

area as having formed through hypogene processes inherently contain an epigenic component because surface denudation has breached them, enabling human entry and study. Therefore, overprinting by epigene processes complicates speleogenetic interpretations. However, overall cave morphology and suites of morphological features provide strong evidence for hypogene speleogenetic origins. Many caves exhibit extensive and complex spatial patterns with cave development that is not supported by their limited surficial drainage areas had they formed by epigene processes. Most caves show evidence of hypogene origins, supporting regional speleogenetic interpretations based on clustering of the surface expression of caves and sinkholes (Stafford et al, 2007b). However, hypogene caves within the Castile Formation are diverse, as shown below. They demonstrate well the continual evolution of speleogenetic systems where caves that have formed by confined ascending fluids are subsequently being overprinted by surficial, epigene processes.

Rectilinear maze caves, commonly attributed to

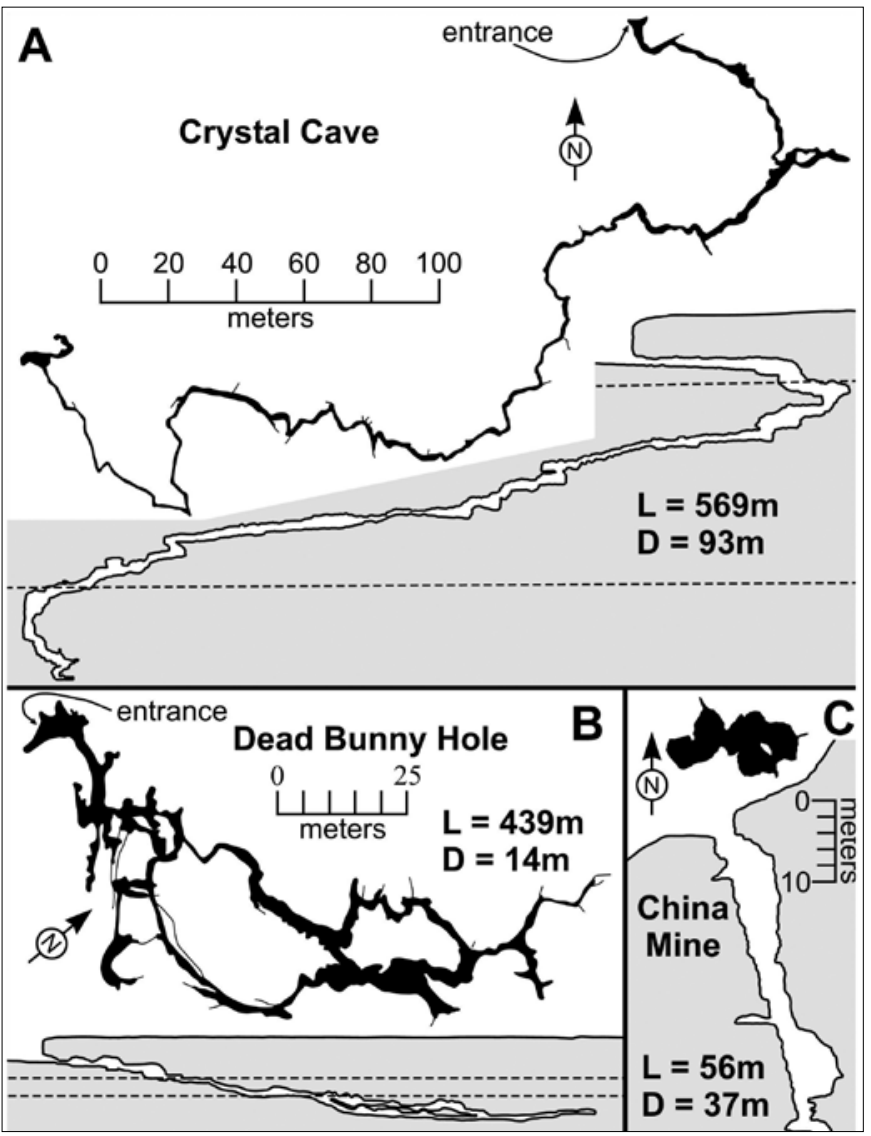

Fig. 13. Simplified maps of representative hypogene caves surveyed during this study in the Castile Formation, including plan view (solid black) and profile (gray outline) views. Note that "L" refers to surveyed length and " $D$ " refers to surveyed depth on individual maps. A) Crystal Cave represents a large single riser system and is developed in a wide range of gypsum fabrics (Culberson Co., Texas) (Dashed line in profile view delineates the approximate boundaries between major changes in lithologic fabric); B) Dead Bunny Hole is a complex cave consisting of anastomotic and maze-like passages within laminated gypsum and calcitized gypsum (Culberson Co., Texas) (Dashed lines in profile view delineate approximate boundaries between cave storeys); C) China Mine is an anthropogenic feature excavated in calcitized gypsum that intersects several isolated hypogene voids (Culberson Co., Texas). Note that all north arrows indicate magnetic north. At the time of survey (Fall 2006) magnetic declination was $\sim 8^{\circ}$ east.

hypogenesis, are uncommon within the Castile outcrop region, most likely because the Castile Formation is not composed of distinctly interbedded lithologies which promote rectilinear maze development. However, many caves exhibit ramiform, maze-like regions or complex patterns composed of ramiform, spongework and anastomotic passage configurations. Parks Ranch Cave is the largest cave documented within the Castile Formation, with $6596 \mathrm{~m}$ of surveyed passage, forming a complex anastomotic pattern (Fig. 14) (Stafford, 2006). However, Dead Bunny Hole (Fig. 13B) is the most complex maze cave documented within the study area, although it has a surficial drainage area of less than one square kilometer. It is developed in both laminated gypsum and calcitized evaporites, with a current surveyed length and depth of 439 meters and 14 meters, respectively. The cave is developed in three offset storeys that decrease in depth towards the northwest, which 


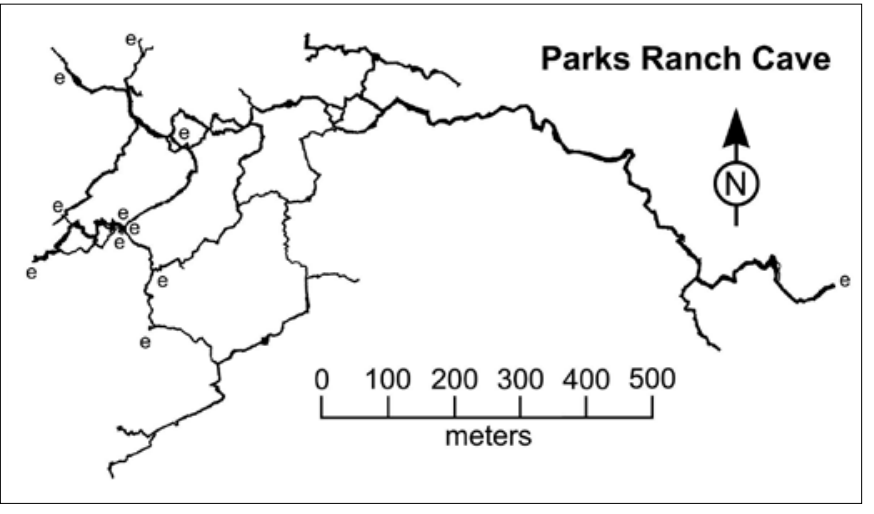

Fig. 14. Plan view map of Parks Ranch Cave which exhibits a complex anastomotic cave pattern (adapted from Stafford, 2006). Parks Ranch Cave is the longest, currently documented cave within the Castile Formation, with a surveyed length of $6596 \mathrm{~m}$. This cave contains significant features indicative of hypogene origins that have been heavily overprinted by epigene processes. The overprinting features show the continuous speleogenetic evolution of karst within the study area. Major entrances are labeled with the letter "e".

largely correspond to lithologic variations in bedrock. The upper and lower levels are developed in laminated gypsum, while the middle level occurs in calcitized evaporites. The southwestern portion of the cave is primarily developed along the fold axes of anticlines (Fig. 5E), while the central and northeastern portions of the cave follow along fractures. Throughout the cave, the floor is mantled with extensive breakdown and allogenic sediments; however, abundant risers (Fig. 12A), outlets or cupolas (Fig. 12C) and half-tubes (Fig. 12B) are distributed throughout, as well as regions of highly porous, boneyard morphology (Fig. 12E). Few scallops, indicative of significant epigene processes, were observed in the cave. The complex cave pattern and associated morphological suite indicate that the cave was originally formed under confined conditions where non-competitive, mixed convection hydrologic flow simultaneously produced solutional conduits along all available fractures and anticlines. Currently, the cave is being overprinted by epigene process, but because of the limited surficial drainage area, much of the original hypogene morphology is preserved.

Many of the hypogene caves of the Castile Formation do not exhibit traditional patterns, but instead occur primarily as single ascending passages, forming the largest and deepest caves within the study area. Crystal Cave (Fig. 13A) is the deepest cave yet identified in the Castile outcrop region, with a length and depth of 569 meters and 93 meters, respectively. From the sinkhole entrance, the cave descends gently, with only two major pits and many small drops. The cave alternates between elliptical passages and tall domal passages, with a small incised canyon along the axis of the floor that is well-developed near the entrance (Fig. 11C) and intermittently throughout the cave. Scallops are only observed on the walls and floor of the incised canyon, suggesting that this portion of the cave was formed by epigene overprinting of the original hypogene morphology. The upper portion of the cave, before the first pit, is developed largely in laminated gypsum. The lowest portion of the cave, the second pit and below, is developed entirely in tabular gypsum (selenite) (Fig. 12D) forming a steeply descending series of small drops beginning at the base of the second pit. The middle portion is developed in a complex suite of gypsum fabrics that alternate between laminated, massive, and nodular tabular fabrics, as well as calcitized evaporites; however, the majority of the middle portion appears to have developed in association with a zone of secondary tabular gypsum (selenite). Cave passage and the associated selenite zone commonly cut across gypsum fabrics at acute angles suggesting that lithologic variability exerted little control on cave development, as would be expected if the cave had formed by descending, meteoric waters; instead, the cave passage development appears genetically related to the occurrence of secondary selenite. Through the majority of the cave, a well-developed ceiling channel is observed along with many small to large cupolas, creating an irregular ceiling profile. The lowest portion of the cave is completely flooded and beyond exploration, but the sump area appears very similar to a large-scale, isolated riser feature. Based on cave morphology and passage development that appears largely associated with secondary tabular gypsum, Crystal Cave was formed as a large, single rising column of water where dissolution was dominated by mixed convection driven by variations in the density of ascending and descending fluids along limited fractures with poor hydraulic connectivity.

Isolated chambers are also observed in most calcitized evaporite masses. These are usually meter-scale ovoid chambers that show no relation to the modern geomorphic landscape, but are developed within highly porous biogenic limestone. Associated with many subsurface calcitized masses are significant accumulations of native sulfur (Hentz \& Henry, 1989). However, minimal native sulfur is observed at surficial exposures of calcitized masses. Therefore, it is logical to assume that the isolated voids found within some calcitized masses are related to sulfuric acid dissolution of the biogenic limestone, where native sulfur in the presence of oxic waters has produced aggressive, sulfuric acid-rich waters (Fig. 3). Of the hypogenic caves formed in calcitized masses, one was previously reported in association with late $19^{\text {th }}$ century mining activity (Phillips, 1917). China Mine (Fig. 13C), also known as Sulfur Mine Cave or Sulphuretted Hydrogen Cave (Hill, 1996; Smith \& Elliott, 1994), is a vertical mine shaft that descends to a depth of 37 meters. Hill (1996) reported this feature as a natural pit cave that had been modified by sulfur mining activity. During this study, the feature was mapped and determined to largely represent an anthropogenic mine shaft that had been excavated along a fracture containing minimal sulfur accumulations. However, five small (less than $10 \mathrm{~m}^{3}$ each), previously undocumented, natural voids were identified (Fig. 11D) at three separate depths. Although the entire feature was originally misinterpreted as a natural cave, the recently documented natural voids which were intercepted during original mining show direct evidence of hypogene speleogenesis within 
calcitized masses.

The examples above exemplify the diversity of the hypogene caves that are developed within the Castile Formation, by providing end member examples of a maze cave (Fig. 13A) and a cave consisting of a single major riser feature (Fig. 13B). Isolated voids within calcitized masses indicate that this is not a phenomenon limited to the gypsum facies, but instead occurs throughout the entire Castile Formation. Although space does not allow, numerous other examples exist within the Castile outcrop region, including several features that contain hydrologically active spring discharge, yet contain clear evidence of hypogene origins (Fig. 11E). Based on abundant aquatic fauna in these caves, the hydrologically active stream caves do not appear to be directly related to seasonal, monsoonal precipitation events. It is more likely that they are related to artesian discharge derived from lower transmissive zones. Future studies on regional hydrology are planned to elucidate the source and flow paths of these hydrologically active features.

\section{Intrastratal breccia}

Throughout the study area and the entire Castile Formation, zones of brecciation are common; however, the manifestations are varied. Vertical breccia pipe structures are widespread and can extend through the entire thickness of the Castile Formation (Hill, 1996). In contrast to vertical breccia structures, laterally extensive blanket breccias frequently occur over wide regions. Commonly, blanket breccias and breccia pipes are manifested as solution subsidence valleys, dissolution troughs and collapse pits. However, all breccia occurrences are genetically related because they form from intrastratal dissolution of evaporites through hypogene speleogenesis, where void space created in the subsurface subsequently collapsed.

Breccia pipes have been documented throughout the Delaware Basin, not only related to the Castile Formation but also the Salado and Rustler Formations (Anderson \& Kirkland, 1980). Large breccia pipes are developed along the northern and eastern margin of the Delaware Basin above the Capitan Reef and extend vertically for hundreds of meters through the Castile and Salado Formations. These breccia pipes are either expressed as negative topographic features where collapse has occurred or as positive relief features where past collapse formed resistant breccias that are now expressed as mounds through topographic inversion related to surface denudation (Bachman, 1980). Anderson and Kirkland (1980) proposed a brine density convection model for breccia pipe development where undersaturated fluids from the Capitan Reef aquifer dissolve overlying evaporites. In their model, undersaturated, low density fluids rise and dissolve overlying evaporites until fluids become saturated. Saturated, high density fluids subsequently sink back to the lower aquifer along the margins of upward stoping solution pipes. Therefore, aggressive waters are continuously delivered to the top of an upward stoping collapse column, while sinking, saturated waters prohibit lateral dissolution along the margins of the collapse structure. Upward stoping and hypogene dissolution continue until surficial breaching occurs, which results in a shift from dissolution dominated brine density convection (i.e. free convection) to dissolution dominated by forced convection with an established outlet for ascending, artesian fluids (Klimchouk \& Andrejchuk, 1996).

Blanket breccias (Fig. 15B) are widespread within the Castile Formation and have been largely associated with dissolution of halite interbeds (Anderson et al, 1972). Halite interbeds were deposited throughout the Castile Formation; however, they have largely been removed from the entire western Delaware Basin through subsurface dissolution resulting in thinning of the Castile Formation to the west and the development of laterally extensive breccia horizons. Most blanket breccias are centimeters to decimeters thick and are believed to have formed by laterally migrating fluids, undersaturated with respect to halite $(\mathrm{NaCl})$, which dissolve salt interbeds such that overlying calcium sulfate beds were no longer supported and collapsed (Anderson et al, 1972). Associated with the solution of halite, increased calcium sulfate dissolution is expected as a result of solute ion pairing (Klimchouk, 1996a), such that brecciation is further enhanced by dissolution of calcium sulfate proximal to dissolved halite interbeds. Solution subsidence valleys, narrow linear topographic lows, occur along the western edge of the Castile outcrop area. They have been shown to form along graben boundary faults up to 75 meters deep, where the lower fault limit is coincident with the upper limit of halite dissolution (Hentz \& Henry, 1989). Larger dissolution troughs occur within the central Delaware Basin, which have been attributed to similar processes in the Castile, Salado and Rustler Formations (Anderson et al, 1978). Many of these larger features have been subsequently filled with thick sequences of Quaternary alluvium (Bachman, 1980).

Throughout the Castile outcrop region, breccia pipes and blanket breccias are common. This region is not underlain by the Capitan Reef aquifer as

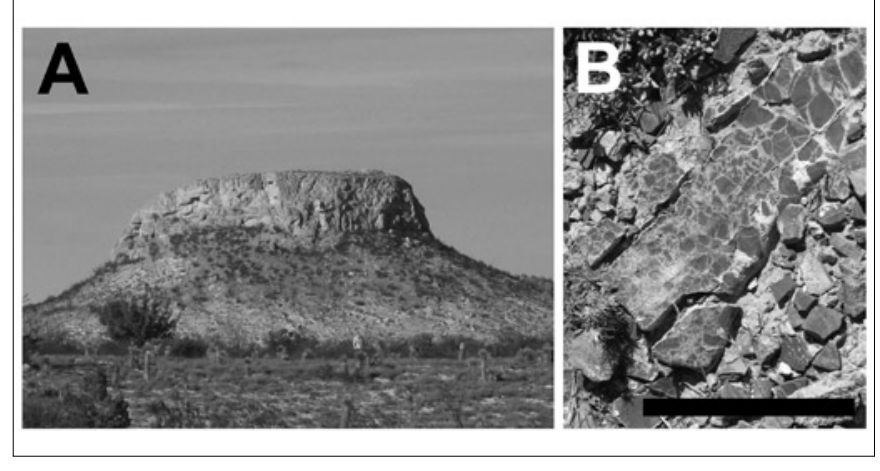

Fig. 15. Intrastratal brecciation and calcitization in the Castile Formation. A) Typical calcitized butte, which forms a residual hill $\sim 40 \mathrm{~m}$ taller than the surrounding gypsum landscape and contains a breccia pipe core; B) Surficial exposure of blanket breccia that is likely the result of intrastratal dissolution of halite and subsequent collapse that has been calcitized. Black scale bar is $\sim 0.5 \mathrm{~m}$ long. 
occurs in the northern and eastern Delaware Basin; however, the evaporites of the central Delaware Basin, including those of the outcrop area, are underlain by the clastic Bell Canyon aquifer which provided the source fluids for hypogene dissolution and formation of brecciated zones (Lee \& Williams, 2000). Many of these brecciated zones are also associated with calcitization where both vertical (Fig. 15A) and laterally extensive calcitized, breccia zones (Fig. 15B) have developed (Kirkland \& Evans, 1976; Hentz \& Henry, 1989). Whether calcitization was contemporaneous with or subsequent to brecciation is unclear. However, the same transmissive and soluble zones that enabled hypogene dissolution and brecciation also have provided many of the preferential flow paths for ascending hydrocarbons that provided the energy source for sulfur reducing bacteria associated with evaporite calcitization (Fig. 3). Therefore, both brecciation and calcitization provide direct evidence of the widespread occurrence of hypogene speleogenesis within the Castile Formation and the entire Delaware Basin.

\section{DISCUSSION AND CONCLUSIONS}

Cave and karst development within the Castile Formation is widespread and diverse, ranging from surficial to intrastratal manifestations associated with both epigene and hypogene speleogenesis. The surficial landscape is dominated by epigenic karst, as is expected for highly soluble, exposed, evaporite rocks. However, cave development and subsurface transmissive zones (e.g. brecciated zones) are dominated by hypogene processes as predicted by cluster analyses of karst feature distribution (Stafford et al, 2007b). Most caves exhibit hypogene origins. More than $55 \%$ of sinkholes are collapse features and the widespread occurrence of calcification and brecciation all suggest that the greater abundance of hypogene karst manifestations observed along the western margin of the Castile outcrop region may be the result of a sampling bias created by surface denudation, because hypogene features inherently form without a direct surface connection. With greater surficial denudation towards the west (Fig. 3), it is probable that a greater proportion of hypogene features will be breached and exposed at the land surface in this region, accounting for the greater abundance of caves within the western portion of the outcrop region. It is probable that numerous other hypogene caves exist in the subsurface to the east, where surface denudation has yet to breach them. By extension of the theory of hypogene speleogenetic dominance in the region, it is likely that hypogene processes continue to actively form solutional conduits and affect calcium sulfate diagenesis in regions where the Castile Formation remains buried in the subsurface to the east. Therefore, as surface denudation continues to strip away overlying strata and the dissolution front of the Castile Formation moves eastward, it is expected that more hypogene caves will be breached to the east, in the down dip direction of the Castile Formation. This eastward shift in denudation will result in continual breaching of hypogene caves that have formed by ascending fluids originating from the underlying Bell Canyon aquifer.

Although karst development appears to be dominated by hypogene processes, epigene processes can significantly overprint evidence of hypogenic origins. Parks Ranch Cave (Fig. 14) is the only cave within the study area that was formally studied prior to current research (Sares, 1984; Nance, 1993). It is a complex, anastomotic cave system with 6,596 meters of surveyed passage (Stafford, 2006), which was interpreted as an epigenic cave formed as a subsurface bypass feature that developed in association with the Black River, an ephemeral spring fed stream located a few kilometers to the north (Sares, 1984). However, extensive evidence of hypogene origins is common throughout the cave, including regions which contain diagnostic morphological features (i.e. risers, cupolas and halftubes). Although the evidence is extensive, numerous regions of the cave have been heavily overprinted by epigene processes. This indicates that it is necessary to study entire caves instead of only the most accessible portions before interpreting speleogenetic origins. Because hypogene karst develops in confined or semiconfined settings, evidence of hypogene processes in caves must predate epigenic development that is forming in equilibrium with the modern climatic regime. Therefore, hypogene speleogenesis formed the initial conduit porosity of Parks Ranch Cave while the region was still in confinement, but epigene processes have utilized these preexisting flow paths and are currently overprinting the original cave system heavily, such that it is difficult to determine the relative importance of epigene and hypogene processes on the formation of this specific cave. Further study of Parks Ranch Cave should reveal interesting details on the local speleogenetic evolution of this small area of the Castile Formation, but it provides little information on the large, basin-scale picture of speleogenesis within the Castile Formation.

Evaporite karst and hypogene speleogenesis are generally underappreciated in North American karst research; however, this investigation has shown that both deserve greater attention in order to better evaluate regional speleogenetic patterns. Hypogene caves and intrastratal breccias within the Castile Formation provide significant insight into basin evolution and previous fluid migration paths within the Delaware Basin. This has implications for not only modern groundwater behavior but also regional hydrocarbon maturation and migration, as associated with evaporite calcitization. The high solution kinetics of calcium sulfate rocks of the Castile Formation results in a landscape that rapidly responds to the modern environment, such that the speleogenetic evolution of the region is preserved to varying degrees. Most caves show extensive evidence of hypogene origins, including complete suites of diagnostic morphologic features. However, hypogene caves exhibit variable degrees of epigenetic overprinting because of surficial breaching, ranging from minor floor entrenchment to significant 
solutional overprinting and large introductions of allogenic sediments. Karst development in the Castile Formation demonstrates that speleogenetic systems need to be viewed from an evolutionary standpoint, because the modern environment only reflects the current stage of development and may not represent the origins of cave and karst features within the region.

\section{ACKNOWLEDGEMENTS}

The authors are grateful to the numerous individuals who made this study possible. Generous land access was provided to private ranches in Texas by Jack Blake, Draper Brantley, Stanley Jobe, Lane Sumner, and Clay Taylor. John Jasper and Jim Goodbar provided assistance with cave and karst studies on BLM (Bureau of Land Management) public land within New Mexico. Volunteer cavers assisted with cave surveys, including: Jim Kennedy, Lucas Middleton, Charley Savvas, Beverly Shade, and Vickie Siegel. Alexander Klimchouk provided many useful discussions on hypogene processes. Research was partially funded by grants from the New Mexico Geological Society (NMGS) and the New Mexico Tech Graduate Student association, with support from the National Cave and Karst Research Institute (NCKRI). The authors are grateful to Jo De Waele, Philippe Audra and an anonymous reviewer for their insightful review comments, which improved this manuscript.

\section{REFERENCES}

Anderson R.Y., Dean W.E., Kirkland D.W. \& Snider H.I., 1972 - Permian Castile varved evaporite sequence, West Texas and New Mexico. Geological Society of America, 83: 59-85.

Anderson R.Y, Kietzke K.K. \& Rhodes D.J., 1978 Development of dissolution breccias, northern Delaware Basin and adjacent areas, bulletin 159. Socorro: New Mexico Bureau of Mines and Mineral Resources: 4752.

Anderson R.Y. \& Kirkland D.W., 1980 - Dissolution of salt deposits by brine density flow. Geology, 8: 66-69.

Bachman G.O., 1980 - Regional geology and Cenozoic history of the Pecos Region, southeastern New Mexico. U.S. Geological Survey Open File Report 80-1099: 117 pp.

Bachman G.O., 1984. Regional geology of Ochoan evaporites, northern part of the Delaware Basin, circular 184. Socorro, New Mexico Bureau of Mines and Mineral Resources: 74 pp.

Barlow C.A. \& Ogden A.E., 1992 - A statistical comparison of joint, straight cave segment, and photo-lineament orientations. NSS Bulletin, 44: 107-110.

Belski D. (Ed.), 1992 - GYPKAP report volume \#2. Albuquerque, Southwestern Region of the National Speleological Society: $57 \mathrm{pp}$.

Calaforra J.M. \& Pulido-Bosch A., 1996 - Some examples of gypsum karsts and the most important gypsum caves in Spain. Int. J. Speleol., 25 (3-4): 225-238.

Calaforra J.M. \& Pulido-Bosch A., 1999 - Genesis and evolution of gypsum tumuli. Earth Surface Processes and Landforms, 24: 919-930.

Calaforra J.M., Pulido-Bosch A. \& Lopes-Chicano M., 2002 - Gypsum karst of the Beltic Cordillera (south Spain). Carbonates and Evaporites, 17 (2): 131-141.

Cantón Y., Sole-Benet A. \& Lazaro R., 2003 - Soilgeomorphology relations in gypsiferous materials of the Tabernas Desert (Almeria, SE Spain). Geoderma, 115 (3-4): 193-222.

Dean W.E., Davies G.R. \& Anderson R.Y., 1975 Sedimentological significance of nodular and laminated anhydrite. Geology, 3: 367-372.

Dickenson W.R., 1981 - Plate tectonic evolution of the southern Cordillera. Arizona Geological Society Digest, 14: 113-135.

Dietrich J.W., Owen D.E., Shelby C.A. \& Barnes V.E., 1995 - Geologic atlas of Texas: Van Horn-El Paso Sheet. Austin, University of Texas Bureau of Economic Geology: 1 sheet.

Eaton J. (Ed.), 1987 - GYPKAP 1987 annual report. Alamogordo, Southwestern Region of the National Speleological Society: $35 \mathrm{pp}$.

Forbes J. \& Nance R., 1997 - Stratigraphy, sedimentology, and structural geology of gypsum caves in east central New Mexico. Carbonates and Evaporites, 12 (2): 6472.

Ford D.C., 2006 - Karst geomorphology, caves and cave deposits: a review of North American contributions during the past half century. In: Harmon, R.S. \& Wicks, C.W. (Eds.) - Perspectives on karst geomorphology, hydrology and geochemistry. Boulder, Geological Society of America: 1-14.

Ford D.C. \& Williams P.W., 2007 - Karst hydrogeology and geomorphology. John Wiley \& Sons: 562 pp.

Frumkin A. \& Fischhendler I., 2005 - Morphometery and distribution of isolated caves as a guide for phreatic and confined paleohydrological conditions. Geomorphology, 67: 457-471.

Hentz T.F. \& Henry C.D., 1989 - Evaporite-hosted native sulfur in Trans-Pecos Texas: relation to late phase Basin and Range deformation. Geology, 17: 400-403.

Hill C.A., 1996 - Geology of the Delaware Basin, Guadalupe, Apache and Glass Mountains: New Mexico and west Texas. Midland, Permian Basin Section of the SEPM: 480.

Horak R.L., 1985 - Trans-Pecos tectonism and its affects on the Permian Basin. In: Dickerson, P.W. \& Muelberger (Eds.) - Structure and Tectonics of Trans-Pecos Texas. Midland, West Texas Geological Society: 81-87.

Hose L.D. \& Pisarowicz J.A. (Eds.), 2000 - The caves of the Guadalupe Mountains. J. Cave and Karst Studies, 62 (2): 157.

Jeschke A.A., Vosbeck K. \& Dreybrodt W., 2001 Surface controlled dissolution rations of gypsum in aqueous solutions exhibit nonlinear dissolution kinetics. Geochimica et Cosmochimica Acta, 65 (1): 27-34.

Johnson K.S., 2002 - Karst in evaporite rocks of the United States. Carbonates and Evaporites, 17 (2): 90-97.

Johnson K.W., Collins E.W. \& Seni S.J., 2003 - Sinkholes and land subsidence owing to salt dissolution near Wink Sink, west Texas, and other sites in western Texas and New Mexico. In: Johnson K.S. \& Neal J.T. (Eds.) 
- Evaporite karst and engineering / environmental problems in the United States. Norman, Oklahoma Geological Survey: 183-196.

Johnson K.S. \& Neal J.T. (Eds.), 2003 - Evaporite karst and engineering / environmental problems in the United States. Norman, Oklahoma Geological Survey: 353 pp.

Kelley V.C., 1971 - Geology of the Pecos Country, southeastern New Mexico. Socorro, New Mexico Bureau of Mines and Mineral Resources: 78 pp.

Kempe S., 1996 - Gypsum karst in Germany. Int. J. Speleol., 25 (3-4): 209-224.

Kendall A.C. \& Harwood G.M., 1989 - Shallow-water gypsum in the Castile Formation - significance and implications. In: Harris, P.M. \& Grover, G.A. (Eds.) Subsurface and outcrop examination of the Capitan shelf margin, northern Delaware Basin. San Antonio, SEPM Core Workshop No 13: 451-457.

Kirkland D.W. \& Evans R., 1976 - Origin of limestone buttes, Gypsum Plain, Culberson County, Texas. American Association of Petroleum Geologists Bulletin, 60: 2005-2018.

Klimchouk A., 1996a - Dissolution and conversion of gypsum and anhydrite. Int. J. Speleol., 25 (3-4): 263274.

Klimchouk A., 1996 b-Gypsum karst of the western Ukraine. Int. J. Speleol., 25 (3-4): 263-274.

Klimchouk A., 2000a - Speleogenesis in gypsum. In: Klimchouk A., Ford D.C., Palmer A.N. \& Dreybrodt W. (Eds.) - Speleogenesis: evolution of karst aquifers. Huntsville, National Speleological Society: 261-273.

Klimchouk A., 2000b - Speleogenesis of the great gypsum maze caves in the western Ukraine. In: Klimchouk A., Ford D.C., Palmer A.N. \& Dreybrodt W. (Eds.) - Speleogenesis: evolution of karst aquifers. Huntsville, National Speleological Society: 431-442.

Klimchouk A., 2000c - Speleogenesis under deepseated and confined conditions. In: Klimchouk A., Ford D.C., Palmer A.N. \& Dreybrodt W. (Eds.) - Speleogenesis: evolution of karst aquifers. Huntsville, National Speleological Society: 244260.

Klimchouk A., 2003 - Conceptualization of speleogenesis in multi-storey artesian systems: a model of transverse speleogenesis. Speleogenesis and evolution of karst aquifers, 1 (2): 1-18.

Klimchouk A., 2007 - Hypogene speleogenesis: hydrogeological and morphometric perspective. Carlsbad, National Cave and Karst Research Institute: $106 \mathrm{pp}$.

Klimchouk A. \& Andrejchuk V., 1996 - Breakdown development in cover beds, and landscape features induced by intrastratal gypsum karst. Int. J. Speleol., 35 (3-4): 127-144.

Klimchouk A. Lowe D., Cooper A. \& Sauro U. (Eds.), 1996 - Gypsum karst of the World: thematic issue. Int. J. Speleol., 25 (3-4): 307.

Kohout F.A., Meisler H., Meyer F., Johnston R., Leve G. \& Wait R., 1988 - Hydrogeology of the Atlantic Continental Margin. In: Sheridan R. \& Grow J. (Eds.) - The geology of North America, the Atlantic Continental Margin. Boulder, Geological Society of America: 463-480.
Land L., 2006 - Hydrogeology of Bottomless Lakes State Park. In: Land L., Lueth V., Raatz B., Boston P. \& Lowe D. (Eds.) - Albuquerque, Caves and karst of southeastern New Mexico: 95-96.

LeeJ. (Ed.), 1996-GYPKAPreportvolume 3, Alamogordo, Southwestern Region of the National Speleological Society: $69 \mathrm{pp}$.

Lee M.K. \& Williams D.D., 2000 - Paleohydrology of the Delaware Basin, western Texas: overpressure development, hydrocarbon migration, and ore genesis. Bulletin of the American Association of Petroleum Geologists, 84 (7): 961-974.

Macaluso T. \& Sauro U., 1996 - Weathering crust and karren on exposed gypsums surfaces. Int. J. Speleol., 25 (3-4): 115-126.

Machel H.G. \& Burton E.A., 1991 - Burial-diagenetic sabkha-like gypsum and anhydrite nodules. J. Sedimentary Petrology, 61 (3): 394-405.

Nance R., 1993 - Application of the standard tablet method to a study of denudation in gypsum karst, Chosa Draw, southeastern New Mexico. MS Thesis, Greely, University of Northern Colorado: $82 \mathrm{pp}$.

Nelson J.W., 1991 - Structural and geomorphic controls of the karst hydrogeology of Franklin County, Alabama. MS Thesis, Mississippi State, Mississippi State University: $165 \mathrm{pp}$.

Phillips W. B., 1917 - The sulphur deposits of Culberson County, Texas. Dallas, Transactions of the Society of Mining Engineers of the American Institute of Mining, Metallurgical and Petroleum Engineers: 1449-1466.

Redell J.R., \& Fiesler R.G., 1977 - The caves of far west Texas. Austin, Texas Speleological Survey: 103 pp.

Sares S.W., 1984 - Hydrologic and geomorphic development of a low relief evaporite karst drainage basin, southeastern New Mexico. MS Thesis, Albuquerque, University of New Mexico: 123 pp.

Sauro U., 1996 - Gypsum karst of Italy. Int. J. Speleol., 25 (3-4): 239-250.

Scholle P.A., Goldstein R.H. \& Ulmer-Scholle D.S., 2004 - Classic upper Paleozoic reefs and bioherms of west Texas and New Mexico. Socorro, New Mexico Institute of Mining and Technology: $166 \mathrm{pp}$.

Smith A.R. \& Elliot W.R., 1994 - Sulpheretted Hydrogen Cave. In: Elliott W.R. \& Veni G. (Eds.) - The caves and karst of Texas. Huntsville, National Speleological Society: $316 \mathrm{pp}$.

Stafford K.W., 2006 - Gypsum karst of the Chosa Draw area. In: Land L., Lueth V.W., Raatz W., Boston P. \& Lowe D. (Eds.) - Caves and karst of southeastern New Mexico. Albuquerque, New Mexico Geological Society: 82-83.

Stafford K.W., Klimchouk A. \& Boston P.J., 2006 Polygenetic evaporite karst of the Castile Formation of the western Delaware Basin. Abstracts and Program. Geological Society of America, 38 (7): 289.

Stafford K.W., Land L. \& Klimchouk A., 2007a Hypogenic speleogenesis within Seven Rivers evaporites: Coffee Cave, Eddy County, New Mexico. J. Cave and Karst Studies, 69 (3): in press.

Stafford K.W., Mylroie J.E., Taborosi D., Jenson J.W. \& Myrloie J.R., 2005 - Karst development on Tinian, CNMI: controls on dissolution in relation to the Carbonate Island Karst Model. J. Cave and Karst Studies, 67 (1): 14-27. 
Stafford K.W., Rosales-Lagarde L. \& Boston P.J., $2007 \mathrm{~b}$ - Castile evaporite karst potential map of the Gypsum Plain, Eddy County, New Mexico and Culberson County, Texas: a GIS methodological comparison. J. Cave and Karst Studies, 69 (3): in press.

Tóth J., 1999 - Groundwater as a geologic agent and overview of the causes, processes, and manifestations. Hydrogeology Journal, 7: 1-14.
Trzhtsinsky Y.B., 2002 - Human-induced activation of gypsum karst in Priangaria (east Siberia, Russia). Carbonates and Evaporites, 17 (2): 154-158.

White W.B., 1988 - Geomorphology and hydrology of karst terrains. New York, Oxford University Press: 464 pp.

Yauro L. \& Cooper A., 2002 - Evaporite karst and resultant geohazards in China. Carbonates and Evaporites, 17 (2): 159-165. 